\title{
NON-PULMONARY TUBERCULOSIS IN ENGLAND AND IN WALES
}

\author{
ACCOUNT OF A GROUP INVESTIGATION UNDERTAKEN DURING \\ THE YEARS 1943 TO 1945*
}

\author{
(REPORT TO THE MEDICAL RESEARCH COUNCIL)
}

\begin{abstract}
Alarmed at the apparent increase in the death-rate from tuberculosis during the first 2 years of the second World War, the Ministry of Health asked the Medical Research Council to investigate the extent and causes of the increase and to advise on possible preventive measures. The Council appointed a committee in the autumn of 1941 , under the chairmanship of the late Lord Dawson of Penn. The Committee's report (Report, 1942), which was issued a year later, showed that the increased incidence had affected not only young men and women, but children and the older male age groups as well. Particularly disturbing was the rise in the non-pulmonary tuberculosis deaths among children-in contrast to the first World War, in which there was an actual decline in the early childhood mortality.

Following on this report one or two members of the Committee thought that it would be interesting to find out how much of the increased death-rate from non-pulmonary tuberculosis was ascribable to infection with the bovine type of bacillus. With the consent of the Medical Research Council a small conference was called at which it was decided to try and carry out an investigation covering the whole of Great Britain. Both the Scottish and Welsh representatives expressed the desire to organize the inquiries for their own countries separately, with the result that the subsequent investigations, though undertaken along much the same lines and subsidized by the Medical Research Council, were carried out independently for England, Wales and Scotland.

Originally it was hoped to combine the results obtained in these three countries into a single joint report for Great Britain, but owing to differences in the method of carrying out the inquiry in the three countries and to the period of time that it covered, such a project had to be abandoned. On the whole, the English and Welsh investigations were fairlv
\end{abstract}

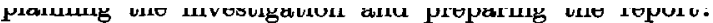
Dr V. D. Allison, Dr P. D'Arcy Hart, Dr J. E. MeCartney, Dr.A. H. T. Robb-Smith, Dr P. Stocks, Prof. W. Tytler, Prof. G. Payling Wright and Prof. G. S. Wilson (Chairman). Dr G. J. G. King assisted in the preparation of the Welsh report.

J. Hygiene 47 closely co-ordinated, and might possibly have been described together. Since, however, the results of the Scottish investigations could not be incorporated with the others, it was decided to publish all three reports separately. The present paper records the findings in England and in Wales.

\section{NON-PULMONARY TUBERCULOSIS IN ENGLAND}

The inquiry was designed to provide, as far as possible, information on the relative frequency of infection with the human and bovine types of tubercle bacillus throughout England. For this purpose material was collected from all over the country. 'Collecting pathologists' situated mainly in hospital laboratories submitted the necessary samples to 'typing bacteriologists', who then forwarded their results to the headquarters of the Public Health Laboratory Service in London. Altogether 149 pathologists at 120 collecting centres and 32 bacteriologists at 27 typing centres took part in the scheme.

At the same time an attempt was made to obtain information on some of the factors associated with the disease in the individual patients, notably exposure to contact with tuberculous patients and the consumption of raw cows' milk.

In practice, two forms were used for each patient. Form A recorded, on the front, the patient's name, age, sex, address, date of illness, clinical history, and any biopsy or autopsy notes available. These data were filled in by the collecting pathologist, and sent with the sample for examination to the typing bacteriologist. The back of Form A provided for a record of the bacteriological examination of the sample, including all microscopical, cultural, and animal inoculation results.

As soon as the infecting organism had been isolated ing bacterio. dical Super-

intendent of the Sanatorium, or other responsible official with a request for information on the patient's occupation, change of address within the preceding 5 years, number of persons in the patient's home, exposure to contact with tuberculous patients in the 
home or at work, and the nature of the milk consumed before and during the war years. When Form B was returned, the typing bacteriologist forwarded both forms to London, where the data were analysed.

\section{Source and nature of material examined}

This report is concerned solely with non-pulmonary tuberculosis. Results on samples of sputum, gastric washings, and pleural fluid have been excluded from the analysis. The material was obtained almost exclusively from patients suffering from nonpulmonary tuberculosis who were admitted to hospitals, sanatoria, or other institutions for diagnosis or treatment. Apart from lymph nodes, it consisted mainly of pus; only a few tissues were submitted for examination. With the exception of some meningitis cases, nearly all samples were derived from patients during life. Again, with the exception of some bone and joint and genito-urinary cases, most of the patients had first shown clinical evidence of the disease within a few weeks or months of examination. The diagnosis was made on clinical grounds, aided when necessary by radiography; and subsequent bacteriological examination showed that it was usually correct. In some cases, howeverparticularly of cervical adenitis-the most careful bacteriological examination failed to reveal the presence of tubercle bacilli in the lesions. Whether these were cases of tuberculosis or of some other disease could not be determined; for the sake of convenience they have been treated in a separate section of the report (p. 348).

It was realized, of course, that this method, though ensuring the collection of material from all parts of England, would not necessarily provide numbers of samples corresponding to the population areas, or to the type of population (urban or rural), from which they were derived, nor proportionately equivalent numbers of samples from different types of nonpulmonary tuberculosis. Thus, since most of the samples would come from patients in institutions, and since some institutions specialized in the treatment of certain types of case, such as bone and joint tuberculosis, it was clear that the material to be examined in any one region would not correspond exactly with the incidence of the different forms of non-pulmonary tuberculosis in that region. No simple method, however, of obtaining a perfectly representative sample of all forms of non-pulmonary tuberculosis seemed to be practicable under the conditions prevailing in wartime, and it was felt that, though the data might be open to criticism in this respect, they would at least be very much superior to those obtained in previous investigations, where the samples had been derived from relatively small and selected areas of the country.
The samples for examination were collected during the war years 1943,1944 , and the first nine months of 1945 .

One of the difficulties in analysing the results has been our ignorance of the true morbidity of nonpulmonary tuberculosis in the different regions. For this reason we have had to base all our conclusions on the proportions existing between the human and the bovine types of bacillus encountered. Comparisons between the apparent incidence of bovinetype infections in different regions and in different age groups have therefore had to be made with great reserve. For instance, a high bovine : human ratio in Region $\mathrm{X}$ compared with Region $\mathrm{Y}$ may mean either that there is a greater risk of infection with the bovine type or a lower risk of infection with the human type in Region $X$ than in Region Y. Without knowing the real rates of attack in the two regions, it is unjustifiable to conclude more than tentatively that the former explanation is correct. We should therefore like to stress that, throughout the report, comparisons have had to be founded on proportions, with resultant uncertainty of the exact weight to be placed on conclusions drawn from them.

\section{Method of isolation and typing the bacilli}

Since the experience of different typing bacteriologists and the facilities available for them varied from one laboratory to another, it was not possible to adhere to a standard method of examination throughout the inquiry. In the larger laboratories the original isolation of the organism was made by both culture and animal inoculation, and the identity of dysgonic strains was confirmed by study of the disease produced in rabbits. In the smaller laboratories, where animals were not provided, isolation was by culture alone; dysgonic strains were reported as bovine if the cultural characters were typical in every respect; otherwise they were sent to one of the larger laboratories for confirmation by animal injection. Strains, whether from large or small laboratories, of whose nature there was any doubt, were submitted to Dr J. A. Young at Cambridge for final identification.

Löwenstein's medium was largely used for cultural purposes; but owing to its selective action on the human type of bacillus, the sample was always inoculated as well on to Dorset's egg medium.

\section{Distribution of specimens according to geographical area and site of disease}

Since the total number of specimens from which tubercle bacilli were isolated amounted to nearly a thousand, it was decided to group the geographical areas in which the patients were located into regions. These differed to some extent from those used by the Registrar-General, and were composed as follows: 
Region

North-East

North-West

North-Midlands

South-Midlands

East

South-East

South-West

London and Middlesex

\section{Counties}

Northumberland, Durham, Yorks

Cumberland, Westmorland, Lancs

Cheshire, Derby, Notts, Salop, Staffs, Leicester, Rutland

Hereford, Worcester, Warwick, Glos, Oxford, Northampton, Bucks, Beds, Herts

Lincoln, Norfolk, Suffolk, Essex, Cambridge, Huntingdon

Kent, Surrey, Sussex, Hants, Berks

Wilts, Somerset, Dorset, Devon, Cornwall

Administrative County of London, Middlesex
Approximate population*

$6,200,000$

$5,000,000$

$\mathbf{5 , 0 0 0 , 0 0 0}$

$5,000,000$

$\mathbf{3}, \mathbf{3 0 0}, 000$

4,700,000

$2,200,000$

$4,300,000$

* Taken from Registrar-General's Report for 1942.

Table 1. Distribution of patients according to geographical region, site of disease, and human or bovine type of infection

Site of disease

\begin{tabular}{|c|c|c|c|c|c|c|c|c|c|}
\hline Region & Туре & $\begin{array}{l}\text { Menin- } \\
\text { gitis }\end{array}$ & $\begin{array}{l}\text { Cervical } \\
\text { glands }\end{array}$ & $\begin{array}{c}\text { Bone } \\
\text { and joint }\end{array}$ & Abdominal & $\begin{array}{l}\text { Genito: } \\
\text { urinary }\end{array}$ & Miscellaneous & $\underset{\text { sites }}{\text { All }}$ & $\begin{array}{c}\text { by type } \\
(\%)\end{array}$ \\
\hline \multirow[t]{2}{*}{ N.E. } & $\begin{array}{l}\mathrm{H} \\
\mathbf{B}\end{array}$ & $\begin{array}{r}24 \\
4\end{array}$ & $\begin{array}{r}13 \\
4\end{array}$ & $\begin{array}{r}57 \\
4\end{array}$ & $\begin{array}{l}2 \\
1\end{array}$ & 6 & $\begin{array}{l}3 \\
1\end{array}$ & $\begin{array}{r}105 \\
14\end{array}$ & $\begin{array}{l}88 \cdot 2 \\
11 \cdot 8\end{array}$ \\
\hline & Total & 28 & 17 & 61 & 3 & 6 & 4 & 119 & $100 \cdot 0$ \\
\hline \multirow[t]{2}{*}{ N.W. } & $\begin{array}{l}\mathrm{H} \\
\mathrm{B}\end{array}$ & $\begin{array}{l}23 \\
20\end{array}$ & $\begin{array}{l}15 \\
24\end{array}$ & $\begin{array}{r}57 \\
6\end{array}$ & - & $\begin{array}{l}6 \\
5\end{array}$ & $\begin{array}{l}6 \\
1\end{array}$ & $\begin{array}{r}107 \\
56\end{array}$ & $\begin{array}{l}65 \cdot 6 \\
34 \cdot 4\end{array}$ \\
\hline & Total & 43 & 39 & 63 & - & 11 & 7 & 163 & $100 \cdot 0$ \\
\hline \multirow[t]{2}{*}{ N. Mid. } & $\begin{array}{l}\mathbf{H} \\
\mathbf{B}\end{array}$ & $\begin{array}{l}23 \\
16\end{array}$ & $\begin{array}{l}13 \\
45\end{array}$ & $\begin{array}{l}59 \\
13\end{array}$ & $\begin{array}{l}2 \\
4\end{array}$ & $\begin{array}{l}4 \\
1\end{array}$ & $\begin{array}{l}4 \\
1\end{array}$ & $\begin{array}{r}105 \\
80\end{array}$ & $\begin{array}{l}56 \cdot 8 \\
43 \cdot 2\end{array}$ \\
\hline & Total & 39 & 58 & 72 & 6 & 5 & 5 & 185 & $100 \cdot 0$ \\
\hline \multirow[t]{2}{*}{ s. Mid. } & $\begin{array}{l}\mathbf{H} \\
\mathbf{B}\end{array}$ & $\begin{array}{r}24 \\
5\end{array}$ & $\begin{array}{l}7 \\
8\end{array}$ & $\begin{array}{r}42 \\
7\end{array}$ & - & $\stackrel{3}{-}$ & 1 & $\begin{array}{l}77 \\
20\end{array}$ & $\begin{array}{l}79 \cdot 4 \\
20 \cdot 6\end{array}$ \\
\hline & Total & 29 & 15 & 49 & - & $\mathbf{3}$ & 1 & 97 & $100 \cdot 0$ \\
\hline \multirow[t]{2}{*}{ East } & $\begin{array}{l}\mathbf{H} \\
\mathbf{B}\end{array}$ & $\begin{array}{r}26 \\
9\end{array}$ & $\begin{array}{l}18 \\
22\end{array}$ & $\begin{array}{r}35 \\
5\end{array}$ & $\begin{array}{l}1 \\
1\end{array}$ & $\begin{array}{l}2 \\
3\end{array}$ & 6 & $\begin{array}{l}88 \\
40\end{array}$ & $\begin{array}{l}68 \cdot 7 \\
31 \cdot 3\end{array}$ \\
\hline & Total & 35 & 40 & 40 & 2 & 5 & 6 & 128 & $100 \cdot 0$ \\
\hline \multirow[t]{2}{*}{ S.E. } & $\begin{array}{l}\mathbf{H} \\
\mathbf{B}\end{array}$ & $\begin{array}{r}32 \\
4\end{array}$ & $\begin{array}{l}\mathbf{5} \\
\mathbf{3}\end{array}$ & $\begin{array}{r}39 \\
3\end{array}$ & $\begin{array}{l}\mathbf{1} \\
\mathbf{3}\end{array}$ & $\begin{array}{r}2 \\
-\end{array}$ & $\underline{3}$ & $\begin{array}{l}82 \\
13\end{array}$ & $\begin{array}{l}86 \cdot 3 \\
13 \cdot 7\end{array}$ \\
\hline & Total & 36 & 8 & 42 & 4 & 2 & $\mathbf{3}$ & 95 & $100 \cdot 0$ \\
\hline \multirow[t]{2}{*}{ S.W. } & $\begin{array}{l}\mathbf{H} \\
\mathbf{B}\end{array}$ & $\begin{array}{r}13 \\
3\end{array}$ & $\begin{array}{r}7 \\
10\end{array}$ & $\begin{array}{r}18 \\
4\end{array}$ & - & 1 & $\underline{3}$ & $\begin{array}{l}42 \\
17\end{array}$ & $\begin{array}{l}71 \cdot 2 \\
28 \cdot 8\end{array}$ \\
\hline & Total & 16 & 17 & 22 & - & 1 & $\mathbf{3}$ & 59 & $100 \cdot 0$ \\
\hline \multirow[t]{2}{*}{$\begin{array}{l}\text { London } \\
\text { and Mddx. }\end{array}$} & $\begin{array}{l}\mathbf{H} \\
\mathbf{B}\end{array}$ & $\begin{array}{l}9 \\
3\end{array}$ & $\begin{array}{l}3 \\
2\end{array}$ & $\begin{array}{r}39 \\
3\end{array}$ & - & 2 & $\stackrel{2}{-}$ & $\begin{array}{r}55 \\
8\end{array}$ & $\begin{array}{l}87 \cdot 3 \\
12 \cdot 7\end{array}$ \\
\hline & Total & 12 & $\mathbf{5}$ & 42 & - & 2 & 2 & 63 & $100 \cdot 0$ \\
\hline \multirow[t]{2}{*}{ Forces, etc. } & $\begin{array}{l}\mathbf{H} \\
\mathbf{B}\end{array}$ & $\begin{array}{l}9 \\
7\end{array}$ & $\begin{array}{l}7 \\
1\end{array}$ & $\begin{array}{r}49 \\
2\end{array}$ & $\overline{2}$ & $\underline{5}$ & $\begin{array}{l}2 \\
1\end{array}$ & $\begin{array}{l}72 \\
13\end{array}$ & $\begin{array}{l}84 \cdot 7 \\
15 \cdot 3\end{array}$ \\
\hline & Total & 16 & 8 & 51 & 2 & 5 & 3 & 85 & $100 \cdot 0$ \\
\hline \multirow{3}{*}{ All } & & & & & Summary & & & & \\
\hline & $\begin{array}{l}\mathbf{H} \\
\mathbf{B}\end{array}$ & $\begin{array}{r}183 \\
71\end{array}$ & $\begin{array}{r}88 \\
119\end{array}$ & $\begin{array}{r}395 \\
47\end{array}$ & $\begin{array}{r}6 \\
11\end{array}$ & $\begin{array}{r}31 \\
9\end{array}$ & $\begin{array}{r}30 \\
4\end{array}$ & $\begin{array}{l}733 \\
261\end{array}$ & $\begin{array}{l}73 \cdot 7 \\
26 \cdot 3\end{array}$ \\
\hline & Total & 254 & 207 & 442 & 17 & 40 & 34 & 994 & $100 \cdot 0$ \\
\hline Bovine (\%) & & $\begin{array}{l}28 \cdot 0 \\
27 \cdot 0\end{array}$ & $\begin{array}{l}57 \cdot 5 \\
46 \cdot 6\end{array}$ & $\begin{array}{l}10 \cdot 6 \\
10 \cdot 8\end{array}$ & $\begin{array}{l}64 \cdot 7 \\
36 \cdot 1\end{array}$ & $\begin{array}{l}22.5 \\
13.9\end{array}$ & $\begin{array}{l}11 \cdot 8 \\
10 \cdot 3\end{array}$ & $\begin{array}{l}26 \cdot 3 \\
23 \cdot 5\end{array}$ & \\
\hline
\end{tabular}

$\mathrm{H}=$ human; $\mathrm{B}=$ bovine.

Figures in black represent percentage of bovine infections if each region is given equal weight.

'Forces, etc.' includes a few patients whose place of residence was not known, and a few who may have been infected outside England. N.E.=North-East; N.W.=North-West; N. Mid. = North-Midlands; S. Mid. = SouthMidlands; E. =East; S.E. $=$ South-East; S.W. = South-West; London and Mddx.=Administrative County of London and County of Middlesex. 
In deciding in which region to include any given patient, attention was paid to the area in which infection was most probably contracted. Thus, a patient who had been living for some years in Region A who came to live in Region B immediately before the onset of his disease was allocated for classification to Region A. On the other hand, if he had moved to Region B more than 2 months before the first sign of illness, he was allocated to Region B, unless the history suggested that infection had occurred in Region A. In instances in which the patient had moved several times before the onset of illness, and in which it was quite impossible to say where infection had occurred, he was allocated to the miscellaneous group entitled 'Forces, etc.' This group contained both male and female members of His Majesty's Forces, together with a very few patients who, though living in England at the time of onset in regions where infection almost certainly did not occur. With most patients, of course, no difficulty arose, since they had been living in the same region all their life or for years before the onset of their illness.

Table 1 shows the distribution of specimens according to the geographical location of the patient at the probable time of infection, the type of infecting bacillus, and the site of the lesion.

Inspection shows that the total number of patients from whom tubercle bacilli were isolated was 994 , and that the proportion of bovine strains was $26 \cdot 3 \%$. Since the number of patients from whom specimens were examined differed in different regions, the proportion of bovine strains isolated has also been calculated on the assumption that each region. comprised the same number of patients; these figures are given in black. Except in lesions, such as abdominal and genito-urinary, where the number

Table 2. Distribution of human and bovine types according to age of patient and site of disease

\begin{tabular}{|c|c|c|c|c|c|c|c|c|c|c|c|c|}
\hline \multirow{3}{*}{ Site of disease } & \multicolumn{10}{|c|}{ Age of patient } & & \\
\hline & \multicolumn{2}{|c|}{$0-$} & \multicolumn{2}{|c|}{$5-$} & \multicolumn{2}{|c|}{$10-$} & \multicolumn{2}{|c|}{$15+$} & \multicolumn{2}{|c|}{ All ages } & \multirow{2}{*}{\multicolumn{2}{|c|}{ Bovine (\%) }} \\
\hline & $\mathrm{H}$ & B & $\mathbf{H}$ & $\mathbf{B}$ & $\mathbf{H}$ & B & $\mathrm{H}$ & B & $\mathbf{H}$ & B & & \\
\hline Meningitis & 80 & 32 & 31 & 17 & 14 & 3 & 57 & 19 & 182 & 71 & $28 \cdot 1$ & $27 \cdot 1$ \\
\hline Cervical glands & 11 & 39 & 15 & 39 & 13 & 19 & 49 & 20 & 88 & 117 & $57 \cdot 1$ & 46.5 \\
\hline Bone and joint & 28 & 8 & 29 & 10 & 26 & 3 & 312 & 26 & 395 & 47 & $10 \cdot 6$ & $10 \cdot 8$ \\
\hline Abdominal & 2 & 4 & - & 2 & - & $\mathbf{3}$ & 4 & 2 & 6 & 11 & $64 \cdot 7$ & $36 \cdot 1$ \\
\hline Genito-urinary & - & - & - & 一 & 1 & 1 & 30 & 7 & 31 & 8 & 20.5 & $12 \cdot 8$ \\
\hline Miscellaneous & 9 & - & 一 & 一 & 2 & I & 18 & 3 & 29 & 4 & $12 \cdot 1$ & $10 \cdot 6$ \\
\hline All sites & 130 & 83 & 75 & 68 & 56 & 30 & 470 & 77 & 731 & 258 & $26 \cdot 1$ & $23 \cdot 4$ \\
\hline Bovine (\%) & & $\begin{array}{l}39.0 \\
38.9\end{array}$ & & $\begin{array}{l}47 \cdot 6 \\
44 \cdot 3\end{array}$ & & $\begin{array}{l}34 \\
\mathbf{3 5}\end{array}$ & & $\begin{array}{l}14 \cdot 1 \\
12.9\end{array}$ & & $\begin{array}{l}26 \cdot 1 \\
23 \cdot 4\end{array}$ & & \\
\hline
\end{tabular}

Five patients omitted owing to their age being unrecorded.

Figures in black represent percentage of bovine infections if each region is given equal weight. $\mathrm{H}=$ human; $\mathrm{B}=$ bovine.

of their illness, had probably contracted infection outside the country. In respect of the Service members, some may have been infected abroad, but the majority appear to have been infected in England. The wisdom of including such a miscellaneous group in the present analysis may be questioned; but as the distribution of human and bovine types appeared to be rnuch the same as in the country as a whole, it was decided to include it. Its omission would decrease the total numbers, but. would have little effect on the proportionate results.

The method of allocation just described is by no means free from criticism. Except in infants, it was often impossible to be certain where infection had occurred. On the other hand, if the address of the patient at the beginning of his illness had been taken as the sole criterion for allocation, a number of patients who had just changed their residence or who were temporarily on holiday would have been included of specimens submitted for examination was small, the two sets of figures are in substantial agreement. Neither of them, of course, represents the real risk of the disease being caused by the bovine type of bacillus, since the age and sex distribution and the site of the disease varied from one region to another. An attempt is made later on (pp. 346-8), by standardizing these factors, to assess more accurately the proportion of human and bovine strains that are likely to be met with in non-pulmonary tuberculous lesions in each of the different regions.

\section{Distribution of human and bovine types according to age of patient and site of disease}

In Tables 2 and 3 the figures have been analysed according to the age of the patient.

The figures for all ages vary slightly from those in Table 1, because five patients had to be omitted from 


\section{Non-pulmonary tuberculosis in England and in Wales}

Table 2 owing to their age being unrecorded. The numbers are not large, but they show that, with the exception of meningitis, the proportion of bovine infections is higher in each of the first three age groups than in the group containing the patients of 15 years and over. Previous observations have revealed the highest proportion of bovine infection for all sites in the 0-4-year age group with a diminishing proportion as age increases. The present series, however, suggests that the bovine proportion is now highest in the 5-9-year age group, and that there is little difference in this respect between the 10-14year age group and that during the first 5 years of life. The difference between the figure of $39.0 \%$ for the 0-4 year and of $47.6 \%$ for the $5-9$-year age group can hardly be considered significant, since it is only 1.6 times its standard error $(5 \cdot 3 \%)$; nevertheless, it is sufficient to show that the proportion of bovine infections in the second quinquennium of life is almost certainly not inferior to that during the first quinquennium. If this is so, it indicates a change in the factors that were responsible previously for the high proportion of bovine infections in infancy and early childhood. A possible explanation for this is put forward on p. 350 .

After the age of 15 years, the proportion of bovine infections falls to about a third of that at ages under 15 years. None the less, it is surprising that as many as $30 \%$ of all bovine infections occurred after this age. There were, in fact, a number of records in quite elderly patients of disease due to the bovine type, such as one case of meningitis, one of bone and joint disease, and two cases of cervical adenitis in patients of 65 years or over. Whether the disease in elderly patients resulted from the flaring up of an old infection that had lain dormant for many years or from a newly acquired infection, it is impossible to say, but the fact that the cervical glands were sometimes affected and that many of the patients gave a recent history of drinking raw milk points towards the second explanation.

Taking non-pulmonary tuberculosis as a whole, it may be said that approximately $40 \%$ of cases under 15 years of age, $15 \%$ of cases in persons aged 15 years and over, and $25 \%$ of cases at all ages were due to infection with the bovine type.

\section{Distribution of human and bovine types according to sex of patient and site of disease}

Table 4 gives the distribution of human and bovine types according to the sex of the patient and the site of disease.

Neglecting the abdominal lesions because of the smallness of the figures, it will be seen that the proportion of bovine infections in female patients was higher than in males, with the exception of menin. gitis cases. The difference for all samples is approxi-

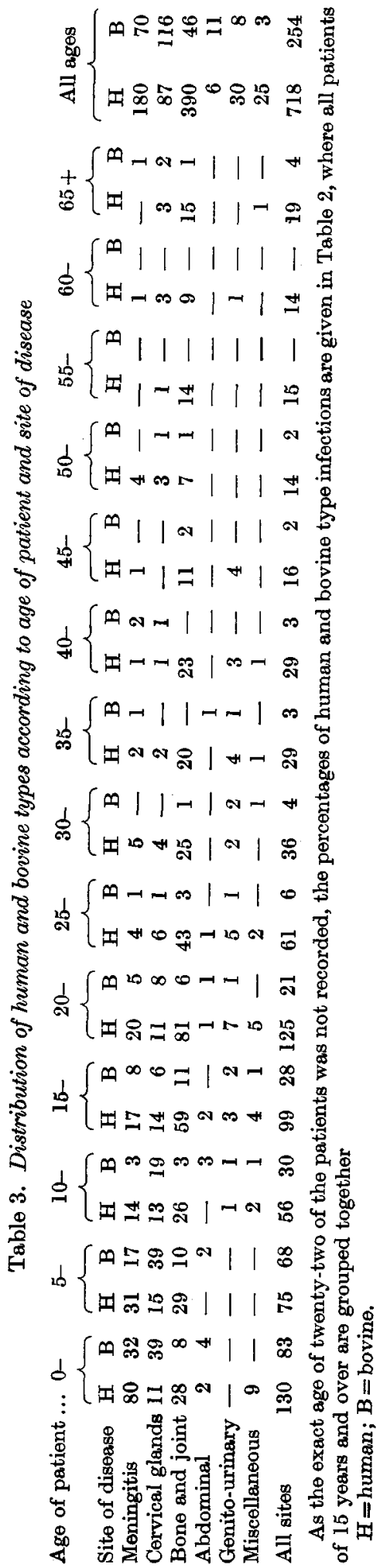


Table 4. Distribution of human and bovine types according to sex of patient and site of disease

\begin{tabular}{|c|c|c|c|c|c|c|c|c|c|c|}
\hline \multirow{3}{*}{$\begin{array}{r}\text { Site } \\
\text { Meningitis }\end{array}$} & \multicolumn{3}{|c|}{ Males } & \multicolumn{3}{|c|}{ Females } & \multicolumn{4}{|c|}{ Persons } \\
\hline & $\mathbf{H}$ & B & $\% \mathrm{~B}$ & $\mathbf{H}$ & B & $\% \mathrm{~B}$ & $\mathbf{H}$ & $\mathbf{B}$ & & \\
\hline & 93 & 39 & $29 \cdot 5$ & 89 & 32 & $26 \cdot 4$ & 182 & 71 & $28 \cdot 1$ & $27 \cdot 0$ \\
\hline Cervical glands & 50 & 52 & $51 \cdot 0$ & 38 & 67 & $63 \cdot 8$ & 88 & 119 & $57 \cdot 5$ & $46 \cdot 6$ \\
\hline Bone and joint & 240 & 27 & $10 \cdot 1$ & 155 & 20 & $11 \cdot 4$ & 395 & 47 & $10 \cdot 6$ & $10 \cdot 8$ \\
\hline Abdominal & 1 & 7 & 87.5 & 5 & 4 & $\mathbf{4 4} \cdot 4$ & 6 & 11 & $64 \cdot 7$ & $36 \cdot 1$ \\
\hline Genito-urinary & 19 & 4 & $17 \cdot 4$ & 12 & 5 & $29 \cdot 4$ & 31 & 9 & $22 \cdot 5$ & 13.9 \\
\hline Miscellaneous & 15 & 2 & $11 \cdot 8$ & 14 & 2 & $12 \cdot 5$ & 29 & 4 & $12 \cdot 1$ & $10 \cdot 6$ \\
\hline All sites & 418 & 131 & $\begin{array}{l}23 \cdot 9 \\
22 \cdot 1\end{array}$ & 313 & 130 & $\begin{array}{l}29 \cdot 3 \\
26 \cdot 6\end{array}$ & 731 & 261 & $26 \cdot 3$ & $23 \cdot 5$ \\
\hline
\end{tabular}

Two patients infected with the human type omitted owing to their sex being unrecorded.

Figures in black represent percentage of bovine infections if each region is given equal weight.

Observed difference for all sites between males and females $=5.4 \%$.

Standard error of this difference $=2 \cdot 8 \%$.

Observed difference divided by its standard error $=1 \cdot 9$.

$\mathrm{H}=$ human; $\mathbf{B}=$ bovine .

mately twice its standard error, that is to say on the border line of conventional significance. The interpretation of this finding is doubtful, and is discussed on p. 351 .

\section{Contact history according to human and bovine type}

The following questions were put to the patient or, if the patient was a child, to the patient's parents.

Have you (or has your child) been in contact with tuberculous persons: (1) in present residence, with dates; (2) in previous residences, with dates; (3) at place of work (or at school), with dates?

If so, state age, sex, and principal site of disease in tuberculous persons to whom the patient was exposed.

Table 5. Contact history according to human or bovine type

\begin{tabular}{|c|c|c|c|c|c|}
\hline ype & $\begin{array}{c}\text { Contact } \\
+\end{array}$ & $\begin{array}{c}\text { Contact } \\
-\end{array}$ & $\begin{array}{c}\text { No } \\
\text { information }\end{array}$ & Total & $\begin{array}{c}\text { Contact } \\
+ \\
(\%)^{*}\end{array}$ \\
\hline H & 164 & 472 & 97 & 733 & $25 \cdot 8$ \\
\hline B & 21 & 20 & 37 & 261 & $9 \cdot 4$ \\
\hline Bot & 185 & 675 & 134 & 994 & $21 \cdot 5$ \\
\hline
\end{tabular}

* Based on cases in which information was available. $\mathrm{H}=$ human; $\mathbf{B}=$ bovine.

Table 5 records the number of cases of human and bovine type in which a history of contact with a pulmonary tuberculosis patient, either at home or at work, was obtained. Unfortunately, the number of patients about whom no information in respect of contact could be obtained was considerable (13.5\%). In many instances, to collect it would probably have required more time than the tuberculosis officer was able to spare. Whether the unavoidable selection of the data caused by the omission of these patients is likely to affect the conclusions to be drawn from the data that are available, it is difficult to say, but this possibility must be borne in mind when interpreting Tables 5-7.

The interest of Table 5 lies in the unexpectedly high proportion $(9.4 \%)$ of cases of bovine infection in which there was a history of human contact. Before commenting on this figure, it is desirable to analyse the human and bovine cases separately according to age.

\section{Contact history according to age of patient and site of disease}

In Table 6 figures relating to contact infection in cases of disease due to the human type are analysed more closely.

The striking feature of this table is the disparity between the figures for the 0-4-year age group and other ages. In the former group a contact history was obtainable in over half the cases, in the rest in only about a quarter. The fact that $56 \%$ of infants and young children affected with non-pulmonary tuberculosis were brought up in contact with tuberculous parents or relations confirms what is a]ready well known, namely that exposure to tuberculous infection at this age entails very real danger. On the other hand, the fact that no contact history was obtained in the remaining $44 \%$ suggests either that tuberculous patients in the child's home had been overlooked, or that tuberculous infection outside the home must be very common, even in the limited environment of the young child. Whichever explanation is correct, it is clear that in about half the cases of non-pulmonary tuberculosis due to the human type in infants and young children, the source of infection remained undiscovered.

It may be noted that when there was a contact history among adults, the contact was almost 
Table 6. Contact history according to age of patient and site of disease (cases of infection with human type only)

\begin{tabular}{|c|c|c|c|c|c|c|c|c|c|c|c|c|c|c|c|c|c|c|c|}
\hline \multirow{2}{*}{$\begin{array}{c}\text { Age of patient... } \\
\text { Site }\end{array}$} & \multicolumn{4}{|c|}{0} & \multicolumn{4}{|c|}{$5-$} & \multicolumn{4}{|c|}{$10-$} & \multicolumn{3}{|c|}{$15+$} & \multicolumn{4}{|c|}{ All ages } \\
\hline & 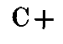 & & & & & & & & & $\mathrm{C}-$ & NI & $\% \mathrm{C}$ & $\mathrm{C}-$ & NI & $\% \mathrm{C}+$ & $\mathrm{C}$ & - & NI & $\% \mathrm{C}+$ \\
\hline Meningritis & 42 & 30 & 8 & $58 \cdot 3$ & 7 & 18 & 6 & 28 & 2 & 7 & 5 & $22 \cdot 2$ & 1140 & 6 & $21 \cdot 6$ & 62 & 95 & 25 & $39 \cdot 5$ \\
\hline & 4 & 6 & 1 & & 2 & $x^{2}$ & 3 & & 3 & 8 & 2 & & $10 \quad 31$ & 8 & & 19 & 55 & 14 & \\
\hline nt & 15 & 10 & $\mathbf{3}$ & $60 \cdot 0$ & 5 & 20 & 4 & $20 \cdot 0$ & 7 & 17 & 2 & $29 \cdot 2$ & $45 \quad 227$ & 40 & $16 \cdot 5$ & 72 & 274 & 49 & $20 \cdot 8$ \\
\hline & - & 1 & 1 & 0.0 & - & 一 & - & - & 一 & - & 一 & - & 2 & 1 & $33 \cdot 3$ & 1 & 3 & 2 & $25 \cdot 0$ \\
\hline & - & 一 & - & - & - & $-\cdots$ & - & - & 一 & 1 & - & 0.0 & 22 & 3 & $18 \cdot 5$ & 5 & 23 & 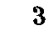 & $17 \cdot 9$ \\
\hline M & 4 & 4 & 1 & $50 \cdot 0$ & - & - & - & - & - & 2 & - & $0 \cdot 0$ & 14 & 3 & $6 \cdot 7$ & $b$ & 20 & 4 & $20 \cdot 0$ \\
\hline All sites & 65 & 51 & 14 & $56 \cdot 0$ & 14 & 48 & 13 & $22 \cdot 6$ & 12 & 35 & 9 & $25 \cdot 5$ & $73 \quad 336$ & 61 & $17 \cdot 8$ & 164 & 470 & 97 & $25 \cdot 9$ \\
\hline
\end{tabular}

Two patients omitted owing to their age being unrecorded.

$\mathrm{C}+=$ history of contact; $\mathrm{C}-=$ no history of contact; $\mathrm{NI}=$ no information; $\% \mathrm{C}+=$ based on cases in which information was available.

Table 7. Contact history according to age of patient and site of disease (cases of infection with bovine type only)

\begin{tabular}{|c|c|c|c|c|c|c|c|c|c|c|c|c|c|c|c|c|c|c|c|c|}
\hline \multirow{2}{*}{$\begin{array}{c}\text { Age of patient... } \\
\text { Site }\end{array}$} & \multicolumn{4}{|c|}{0} & \multicolumn{4}{|c|}{$5-$} & \multicolumn{4}{|c|}{$10-$} & \multicolumn{4}{|c|}{$15+$} & \multicolumn{4}{|c|}{ All ages } \\
\hline & & $\mathrm{C}-$ & $\mathrm{N}$ & & & & & & & C & & $\mathrm{C}+$ & $\mathrm{C}+$ & $\mathrm{C}-$ & NI & $\% \mathrm{C}+$ & $\mathrm{C}+$ & $\mathrm{C}-$ & NI & $\% \mathrm{C}+$ \\
\hline Meningitis & 3 & 24 & 5 & $11 \cdot 1$ & - & 15 & 2 & 一 & - & 2 & 1 & - & 3 & 13 & 3 & $18 \cdot 8$ & 6 & 54 & 11 & $10 \cdot 0$ \\
\hline nds & 1 & 34 & 4 & $2 \cdot 9$ & 2 & 33 & 4 & & 2 & 17 & - & & 2 & 17 & 1 & & 7 & 101 & 9 & \\
\hline $\operatorname{int}$ & - & 6 & 2 & - & 3 & 7 & - & $30 \cdot 0$ & 1 & 2 & - & $33 \cdot 3$ & 1 & 18 & 7 & $5 \cdot 3$ & 5 & 33 & 9 & $15 \cdot 2$ \\
\hline bo & - & 2 & 2 & - & - & l & 1 & $\ldots$ & 1 & 2 & $\ldots$ & $\mathbf{3 3} \cdot \mathbf{3}$ & - & I & I & - & 1 & 6 & 4 & $14 \cdot 3$ \\
\hline$y$ & - & - & - & - & - & - & - & - & - & $\mathbf{l}$ & - & 一 & 2 & 4 & 1 & $33 \cdot 3$ & 2 & 5 & 1 & $28 \cdot 6$ \\
\hline discellan & 一 & - & - & - & - & - & - & - & 一 & 1 & - & 一 & - & 3 & - & - & - & 4 & - & - \\
\hline tes & 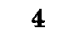 & 66 & 13 & 7 & 5 & 56 & 7 & $8 \cdot 2$ & 4 & 25 & 1 & $13 \cdot 8$ & & 56 & 13 & $2 \cdot 5$ & 21 & 203 & 34 & \\
\hline
\end{tabular}

Three patients omitted owing to their age being unrecorded.

$\mathrm{C}+=$ history of contact; $\mathrm{C}-=$ no history of contact; $\mathrm{NI}=$ no information; $\% \mathrm{C}+=$ based on cases in which information was available.

invariably a home, and not a work, contact. For this reason the figures among adults may be compared with those obtained during a mass radiography survey carried out by the Medical Research Council in London (Clark et al., 1945). At ages 14-34 years a history of home contact was obtained in $17.1 \%$ of patients who had been previously diagnosed as suffering from pulmonary tuberculosis. In our investigation, on non-pulmonary tuberculosis, a similar history was obtained in $17.8 \%$ of patients aged 15 years and over.

In Table 7 figures relating to bovine infection are presented.

The differences between Tables 6 and 7 are striking. In Table 6 the proportion of cases giving a history of contact diminishes, on the whole, with age; in Table 7 the reverse occurs. In the first three age groups a history of contact is much commoner in the human than in the bovine cases, but in the last age group containing persons of 15 years and over the difference between the two is comparatively small. The older the patient, the greater is the likelihood of his having been in contact at some time or another with an open case of pulmonary tuberculosis; this is presumably the reason why $12.5 \%$ of the patients in the last age group infected with the bovine type gave a positive history of contact. The absence of any such upward trend in Table 6 makes the relatively high proportion of patients under 5 years of age giving a positive history of contact all the more striking.

It might, of course, be argued that many of the patients in this series came into contact with cases of pulmonary tuberculosis suffering from infection with the bovine type, and that they became infected by the respiratory tract and not by the consumption of milk. Such an explanation, however, would presuppose an abnormally high proportion of bovine. type infections among pulmonary tuberculosis patients. The evidence gathered before the war showed that only 1-2 \% of human cases of pulmonary tuberculosis in England were due to infection with the bovine type of bacillus (see Topley \& Wilson, 1946). If this proportion still holds true, then it may be concluded that not more than about $0.3 \%$ of the patients in this series had a history of contact with a case of pulmonary tuberculosis due to the bovine type. 
It is possible, of course, that the relevant question on Form B was misinterpreted by some of those who were responsible for filling in the answer. Or it may be that a mild re-infection with bacilli of the human type can re-activate a latent bovine lesion; this possibility should be susceptible to experimental study in animals.

If, however, the view is accepted that the history of contact obtained in over $9 \%$ of our patients infected with the bovine type was fortuitous, and was aetiologically unrelated to their disease, there is clearly a danger of assuming that every patient infected with the human type of bacillus has necessarily contracted his infection from a known human case in his vicinity. Assuming that the figure of $9.4 \%$ is more or less representative of the frequency with which a contact history would be obtained for any group of persons having a similar age, sex, and social distribution to that in the present series, we must deduce that in only two out of three cases will a history of contact point to the true source of infection. This conclusion has no particular relevance to the present investigation, but it may be noted by tuberculosis officers and others interested in the epidemiology of tuberculosis.

\section{Relationship between occupation and infection with human or bovine type of tubercle bacillus}

Information under this head was not very complete and analysis of the data that were available seemed to throw little or no light on factors that might have been responsible for predisposing to infection with the human or the bovine type. In view of pressure on space it does not seem justifiable, therefore, to include the relevant tables. The only serious difference noticed between the two types of infection was that $\mathbf{7 8 . 4} \%$ of patients infected with the bovine type were of pre-school or school age, as against only $44.0 \%$ infected with the human type. This, however, is largely a reflexion of the different age distribution of the two groups (see Table 2).

\section{Relationship between change of residence and infection with human or bovine type of tubercle bacillus}

Information was asked for, on Form B, for the patient's place of residence before and during the war in the hope that it might shed some light on whether tuberculosis was particularly common among evacuees.

Analysis of the data, which were far from complete, revealed a difficulty that should have been foreseen, namely that figures of this sort could not be interpreted satisfactorily in the absence of similar information about persons who did not contract tuberculosis. The finding, for example, that in cases of tuberculous meningitis about $20 \%$ had changed their residence since the outbreak of war might point to an unduly high incidence of disease among evacuees, or, on the other hand, it might be explained on the ground that most of the meningitis cases occurred in children and that children were more often evacuated than adults. It does not seem justifiable, therefore, to set out the figures in tabular form.

The differences between patients infected with the human and those with the bovine type were small. In each group about $25 \%$ gave a history of change of residence as the result either of evacuation or of some other cause. It is probable that some of the patients infected with the human type contracted their disease as the result of exposure to an open case of tuberculosis in the new quarters to which they moved, and that some of the patients infected with the bovine type contracted their disease from the consumption of raw milk in small provincial towns and country districts after having been accustomed to a pasteurized milk supply in the larger towns where they lived originally. The extent, however, to which change of residence led to the development of disease is impossible to estimate in the absence of information about the population in general. All that can be said is that it does not appear to have acted differentially to any great extent in respect of infection with the human or bovine types.

\section{Incidence of non-pulmonary tuberculosis and number of persons in the home}

Information was asked for on Form B about the residential conditions under which the patient lived, namely the number of rooms in the house and the number of their occupants, in the hope of finding out whether overcrowding predisposed to infection with the human type of bacillus. Analysis of the first 150 cases, however, threw grave doubt on the reliability of some of the information provided, and it was decided that further examination of the figures would not be justified.

\section{Consumption of raw milk according to human and bovine types}

An attempt was made to obtain information on the nature of the milk supply for each patient in the series. The following questions were asked:

(1) Before the war did the patient habitually consume: (a) raw cow's milk; (b) pasteurized, sterilized, or otherwise effectively heat-treated milk?

(2) During the war has the patient consumed raw liquid cows' milk at home, school, or elsewhere, and, if so, for approximately how long?

(3) If nature of milk is unknown or doubtful, give 


\section{Non-pulmonary tuberculosis in England and in Wales}

address of dairy, school, or canteen from which milk was obtained.

Many of the answers to these questions were unsatisfactory; sometimes no information could be obtained, and sometimes it was so confused or contradictory that it had to be neglected. When question 3 was answered, a letter was sent from London to the dairyman to ascertain the true facts. For the purposes of the analysis given in Table 8, we have divided patients into those giving and those not giving a history of raw milk consumption. was no reason to suppose that the proportion of patients with a history of drinking raw milk was different from that in the $75 \%$ for whom this information was obtainable.

It may be wondered why, if raw milk is practically the only source of infection with the bovine type, not all the patients infected with this type admitted to drinking raw milk. The reasons are probably numerous. Many parents, for example, obtained a raw milk supply from their dairyman, but said that they always boiled the milk before giving it to

Table 8. Consumption of raw cows' milk according to age and to human or bovine type

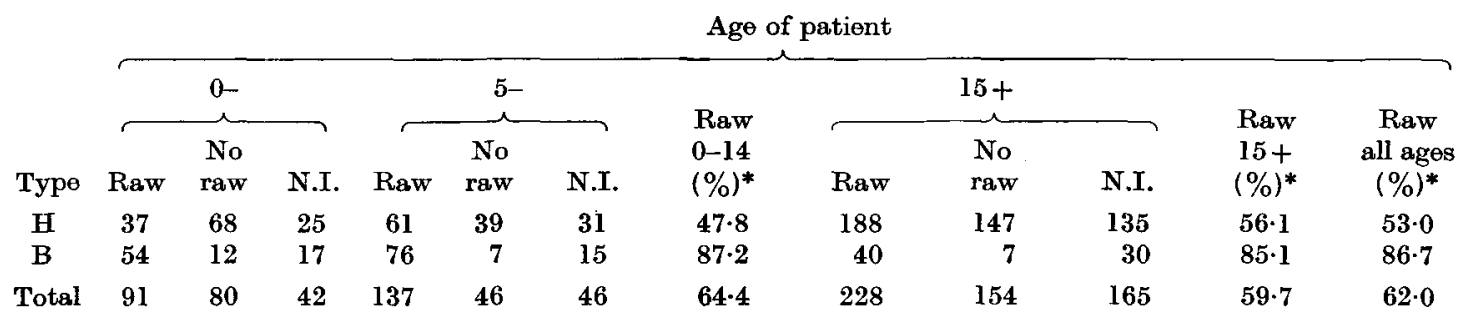

* Based on patients for whom information was available.

Five patients omitted owing to their age being unrecorded.

$\mathbf{H}=$ human; $\mathbf{B}=$ bovine; N.I. = no information.

Observed difference between history of raw milk consumption in human and bovine infections at all ages $=33 \cdot 7 \%$.

Standard error of this difference $=4.05 \%$.

Observed difference divided by standard error of difference $=8 \cdot 3$.

It will be seen that, in respect of patients about whom a reliable history could be obtained, $53.0 \%$ infected with the human type and $86.7 \%$ infected with the bovine type gave a history of drinking raw milk. The difference between these percentages is highly significant, and strongly suggests that, other things being equal, persons drinking raw milk are more likely to develop infection due to the bovine type of bacillus than those drinking heat-treated milk.

Since the proportions of children and adults in the human and bovine groups are so different, it might be maintained that the difference in the consumption of raw milk between the human and bovine groups at all ages was due not to the type of the infecting organism but to the fact that the drinking of raw milk in children was commoner than in adults. That this is not so is perfectly clear from the table, which shows that both in childhood and in adult life bovine infections are far more of ten associated with a history of drinking raw milk than human infections.

Weight is added to the probable truth of this conclusion when it is pointed out that for both the human and the bovine groups there was little difference in the proportion of the total number of patients for whom information about the nature of the milk supply was obtainable $(73.9$ as against $76.0 \%$ ), and that in the missing $25 \%$ or so there their children. It needs little knowledge or imagination to realize that occasions may occur when boiling is omitted by mistake or forgetfulness, or is inadequately carried out. Some patients probably believed that their milk was officially pasteurized, when in factit was either raw or only flash-pasteurized. Again, though the information given by the patient about his ordinary supply was correct, he may have overlooked the fact that he not infrequently drank milk from other sources, such as when on holiday, visiting relatives or friends, or taking meals out.

In going through the individual records, it was striking to notice the number of instances in which infection with the bovine type occurred in the families of farmers or in people visiting or living on farms. There were cases of meningitis in infants who had been brought up on the breast or on dried milk, and then transferred to raw milk. There were cases in which the child had only pasteurized milk at home, but drank raw milk at school. There were numerous cases in which the child had been evacuated from a town, where pasteurized milk had been supplied, to a country district where he was put on to raw milk. There were a few instances in which two or more persons had apparently been infected with milk from the same dairy, and a few in persons who confessed to drinking raw milk only in tea. Many of the records suggested that the consumption of raw 
milk must have been only slight or occasional, pointing to the danger of drinking raw milk at any time or in any form.

\section{Regional distribution of human and bovine types standardized for age and sex}

In the past, none of the data on the distribution of tuberculosis of bovine origin in England has been sufficiently representative of the country as a whole to supply accurate information on the relative chances of infection with the bovine type in different parts of the country. They have pointed to the conclusion that the risk of infection is greater in the north than in the south, but have not justified a closer analysis in relation to other geographical areas.

An attempt has therefore been made with the present data to assess the relative frequency of infection with the bovine type on a regional basis, and thus provide up-to-date information on the chances of finding the bovine type of bacillus in cases of non-pulmonary tuberculosis in different parts of the country. Since Tables 1-4 have shown that the frequency of infection with the bovine type varies according to the site of disease and the age and sex of the patient, and since the specimens submitted for examination from the different regions differed considerably in these respects, it was necessary to standardize the data in order to render them strictly comparable with each other. In Table 9 the data for the different regions are standardized according to age and sex for all sites of disease.

The method of standardization was as follows: For each group of diseases-meningitis, cervical glands, etc. - the proportion of bovine strains for all England was calculated separately for males and females in each age group. These proportions were applied to the total number of cases of the disease for each sex group and age group in each region. In this way, the total expected number of cases of each disease in each region in males and females was worked out, and the ratio of observed to expected cases ascertained.

The bottom row of this table shows that, except in the first 5 years of life, when the figures are almost identical, the ratio of bovine to human type infections is greater in females than in males. The differences, in fact, between males and females increase more or less progressively with age, till in patients of 15 years and over the proportion of bovine infections in females is nearly double that in males. The difference in this last age group is 2.8 times its standard error $(2 \cdot 99)$ and, in the usual statistical terminology, can therefore be regarded as significant. The reason for this difference is not clear; it is discussed on p. 351 .

In Table 10 is set out the ratio of observed cases of infection with the bovine type of bacillus for different sites of disease in different regions to the cases expected on the assumption that the age- and sexrates in each region were the same as those for the aggregate of all regions. It must be clearly understood that this table shows not the risk of contracting non-pulmonary tuberculosis of bovine origin, but merely the relative probability in the different regions of finding bovine-type bacilli in the cases of non-pulmonary tuberculosis that do occur.

Inspection of the individual columns reveals a number of curious discrepancies between the regions. Why is it, for example, that the North-Western region has a high proportion of bovine infections in meningitis cases and a comparatively low proportion in cases of cervical adenitis, whereas the South-Midland and South-Western regions have the reverse distribution? Or why is the proportion of bovine infections in bone and joint cases, in relation to all sites of disease, so high in the North-Midlands and South-West and so much lower in the NorthWest? Unfortunately, the number of cases in each of these subdivisions is too small to justify the conclusion that the differences noted are due to causes other than chance, and it is therefore impossible to do more than draw attention to such discrepancies, in the hope that the collection of further data may help to clarify the issue.

When all sites of disease are considered, striking differences are noticed between the different regions. The highest proportion of infections due to the bovine type is in the North-West and North-Midlands, the lowest in the North-East, South-East, and the London-Middlesex area. The high figures for the North-Western and North-Midland regions need occasion no surprise, since the cattle in these regions are known to be heavily infected with tuberculosis; but the very low figure for the North-Eastern region, for example, requires explanation.

As has already been pointed out, it must be remembered that the figures given here are based on proportions, not on attack-rates, and it may be suggested that the low ratio of observed to expected cases of bovine infection in the North-East region is due not to a lower incidence of bovine-type infections, but to a high incidence of human-type infections associated with the prevalence in this region of pulmonary tuberculosis. Inspection, however, of Table 11 lends very little support to this explanation. For example, though the North-East region has a fairly high respiratory tuberculous death-rate, the bovine: human ratio in nonpulmonary tuberculosis is lower than in any other region. London provides an even greater exception, having the highest respiratory tuberculosis deathrate with the lowest-but-two bovine: human ratio in non-pulmonary tuberculosis; and the NorthWest region with the second highest respiratory tuberculosis death-rate has also the second highest 


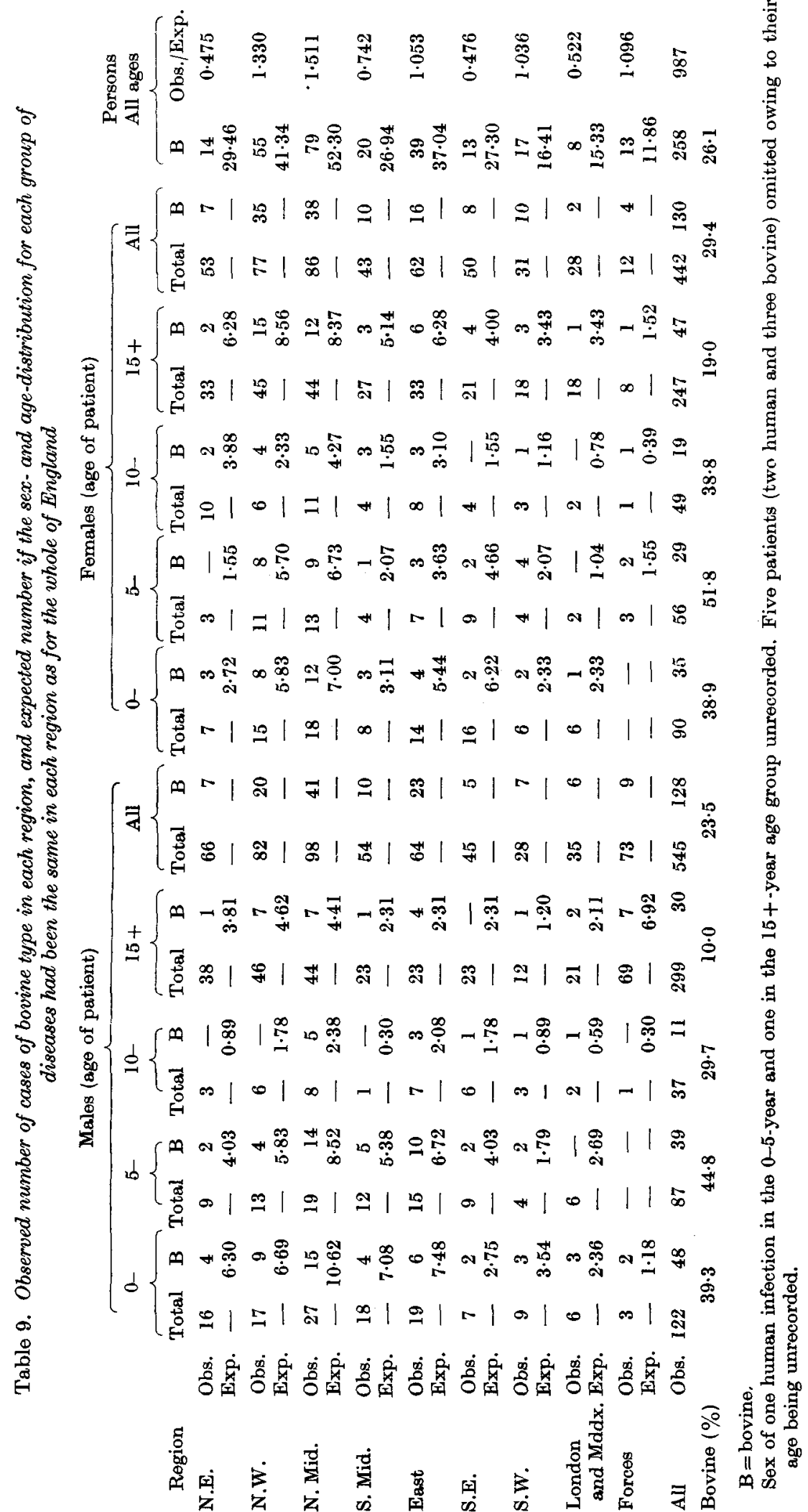


Table 10. Ratio of observed to expected cases of bovine infection according to region, and site of disease

\begin{tabular}{|c|c|c|c|c|c|c|c|}
\hline Region & Meningitis & $\begin{array}{l}\text { Cervical } \\
\text { glands }\end{array}$ & $\begin{array}{c}\text { Bone } \\
\text { and joint }\end{array}$ & Abdominal & $\begin{array}{l}\text { Genito- } \\
\text { urinary }\end{array}$ & Miscellaneous & All sites \\
\hline N.E. & 0.514 & $0 \cdot 465$ & 0.583 & 0.714 & - & $1 \cdot 887$ & 0.475 \\
\hline N.W. & $1 \cdot 657$ & $1 \cdot 061$ & $0 \cdot 892$ & - & $2 \cdot 646$ & $1 \cdot 667$ & $1 \cdot 330$ \\
\hline N. Mid. & $1 \cdot 423$ & 1.253 & $1 \cdot 650$ & $1 \cdot 053$ & 0.935 & $0 \cdot 787$ & $1 \cdot 511$ \\
\hline S. Mid. & 0.584 & $1 \cdot 060$ & $1 \cdot 135$ & - & - & - & 0.742 \\
\hline East & 0.908 & $0 \cdot 862$ & $1 \cdot 269$ & $1 \cdot 000$ & $1 \cdot 538$ & - & 1.053 \\
\hline S.E. & $0 \cdot 430$ & $0 \cdot 600$ & $0 \cdot 701$ & $1 \cdot 071$ & - & - & $0 \cdot 476$ \\
\hline S.W. & $0 \cdot 685$ & $1 \cdot 038$ & $1 \cdot 429$ & - & - & - & $1 \cdot 036$ \\
\hline London and Mddx. & 0.845 & 0.727 & $0 \cdot 658$ & - & - & - & 0.522 \\
\hline Forces, etc. & $1 \cdot 659$ & $0 \cdot 877$ & 0.559 & $1 \cdot 000$ & - & $2 \cdot 000$ & $1 \cdot 096$ \\
\hline
\end{tabular}

Dashes indicate that there were no observed cases.

bovine: human ratio in the non-pulmonary form of the disease.

Table 11. Approximate mortality rate from respiratory tuberculosis in England according to regions (based on Registrar-General's 1942 figures)

$\begin{array}{lcc} & \text { Rovine: human } \\ \text { Region } & \mathbf{1 , 0 0 0 , 0 0 0} & \begin{array}{c}\text { ratio in } \\ \text { non-pulmonary } \\ \text { tuberculosis* }\end{array} \\ \text { North-East } & 520 & 0.475 \\ \text { North-West } & 620 & 1.330 \\ \text { North-Midlands } & 470 & 1.511 \\ \text { South-Midlands } & 490 & 0.742 \\ \text { East } & 450 & 1 \cdot 053 \\ \text { South-East } & 480 & 0.476 \\ \text { South-West } & 430 & 1 \cdot 036 \\ \text { London and Middlesex } & 740 & 0.522\end{array}$

Note. This table was prepared by adding up the deaths from respiratory tuberculosis in the counties and county boroughs contained in the regions listed on p. 339 and working out the death-rate per 1,000,000 according to the population of these regions.

* Copied from the last column of Table 10.

Without information on the true morbidity rates, it is impossible therefore to decide how far the ratios given in Table 10 reflect the total incidence of bovinetype infections in the different regions, and how far the frequency of open cases of pulmonary tuberculosis. The only justifiable conclusion is that the chances of non-pulmonary tuberculous infections being of bovine origin vary considerably from region to region.

\section{Cases not proved bacteriologically to be tuberculous}

There were a number of cases diagnosed on clinical grounds as eases of tuberculosis in which careful bacteriological examination failed to reveal the presence of tubercle bacilli. Figures of these cases have been examined to see whether analysis can throw any light on their probable nature. Unfortunately, there is reason to believe that the available figures are not complete, and that not all cases in which the bacteriological results were negative were reported to headquarters in London. Such as they are, however, they may be briefly summarized.

In Table 12 the figures are classified according to the age of the patient and the site of disease.

Table 12. No tubercle bacilli isolated. Distribution according to age of patient and site of disease

\begin{tabular}{|c|c|c|c|c|c|c|}
\hline \multirow[b]{2}{*}{ Site of disease } & \multicolumn{4}{|c|}{ Age of patient } & \multicolumn{2}{|c|}{ All ages } \\
\hline & 0 & $5-$ & $10-$ & $15+$ & No. & $\begin{array}{c}\text { Per- } \\
\text { centage }\end{array}$ \\
\hline Meningitis & 3 & - & 1 & 1 & 5 & $\mathbf{3} \cdot \mathbf{0}$ \\
\hline Cervical glands & 17 & 45 & 32 & 41 & 135 & $81 \cdot 3$ \\
\hline Bone and joint & 4 & 1 & 1 & 11 & 17 & $10 \cdot 2$ \\
\hline Abdominal & 1 & 1 & 一 & 2 & 4 & $2 \cdot 4$ \\
\hline Genito-urinary & - & - & - & 2 & 2 & 1.2 \\
\hline Miscellaneous & - & - & - & 3 & 3 & $1 \cdot 8$ \\
\hline All sites: & & & & & & \\
\hline No. & 25 & 47 & 34 & 60 & 166 & - \\
\hline Percentage & $15 \cdot 1$ & $28 \cdot 3$ & $20 \cdot 5$ & $36 \cdot 1$ & - & - \\
\hline
\end{tabular}

Six patients omitted owing to their age being unrecorded.

It will be seen that over four-fifths of the cases were of cervical adenitis, and that these were commoner in the higher age groups than in the 0-4-year age group.

Further analysis showed no difference in the incidence between males and females, but did show that cases in which no tubercle bacilli could be demonstrated were far commoner in some regions than in others; for example, 132 out of 172 of the specimens were derived from the North-East, the North-Midlands, and the South-West. No satisfactory explanation for this difference was forthcoming.

It is unfortunately impossible to say whether the 


\section{Non-pulmonary tuberculosis in England and in Wales}

cases summarized in Table 12 were really cases of tuberculosis or not. Very few glands were examined histologically, and those that were did not show typically tuberculous lesions. The differential diagnosis of tuberculous cervical adenitis is often difficult (see Bailey, 1948), and it may be that some of the glands sent for examination were from patients affected with other diseases. Whatever their nature, it seems desirable to investigate cases of this type more fully, and find out whether the failure to isolate tubercle bacilli is due to the inadequacy of our laboratory methods or to wrong diagnosis on the part of the clinicians.

\section{Discussion}

(a) Relative proportion of bovine infections now and formerly

The proportions of non-pulmonary infections in England due to the bovine type of tubercle bacillus in 1943-5 may be usefully compared with those given by Griffith in 1938 (Table 13).

Griffith's figures, it should be pointed out, were rather greater than its standard error, is likewise insignificant. On the other hand, the proportion of bovine infections in bone and joint lesions is considerably higher in Griffith's than in the present series - 19.7 and $10.6 \%$-and the difference is more than three times its standard error $(2 \cdot 3 \%)$ and must therefore be regarded as significant. Unfortunately, Griffith, in his 1938 paper, did not give figures for abdominal tuberculosis, but from information provided in some of his earlier papers, and summarized in the Committee on Cattle Diseases Report (Report, 1934), it is clear that he found a high proportion of bovine infections in abdominal lesions, especially in the first few years of life. The higher proportion of bovine infections in bone and joint lesions may perhaps be attributed to the fact that most of Griffith's figures for this form of disease were collected at the beginning of his series, when bovine infections may perhaps have been rather commoner than they are now.

If the proportions for all sites of disease are com. pared, very little difference is noted between the two series. The explanation for this may be that bovine

Table 13. Proportion of non-pulmonary bovine infections in England according to age of patient and site of disease. Comparison of figures in this report with those of Griffith in 1938

\begin{tabular}{|c|c|c|c|c|c|c|c|c|c|c|c|c|}
\hline \multirow{3}{*}{$\begin{array}{l}\text { Age of patient... } \\
\text { Site of disease }\end{array}$} & \multicolumn{6}{|c|}{ Present report } & \multicolumn{6}{|c|}{ Griffith's report } \\
\hline & \multicolumn{2}{|c|}{$0-4$} & \multicolumn{2}{|c|}{$5-14$} & \multicolumn{2}{|c|}{ All ages } & \multicolumn{2}{|c|}{$0-4$} & \multicolumn{2}{|c|}{$5-14$} & \multicolumn{2}{|c|}{ All ages } \\
\hline & No. & $\% \mathrm{~B}$ & No. & $\% \mathbf{B}$ & No. & $\% \mathbf{B}$ & No. & $\% \mathrm{~B}$ & No. & $\% \mathrm{~B}$ & No. & $\% \mathbf{B}$ \\
\hline Meningitis & 112 & $28 \cdot 6$ & 65 & $30 \cdot 8$ & 253 & $28 \cdot 1$ & - & $28 \cdot 1$ & - & $24 \cdot 5$ & 265 & $24 \cdot 6$ \\
\hline Cervical glands & 50 & $78 \cdot 0$ & 86 & $67 \cdot 4$ & 205 & $57 \cdot 1$ & - & $91 \cdot 3$ & - & $54 \cdot 2$ & 128 & $50 \cdot 0$ \\
\hline Bone and joint & 36 & $22 \cdot 2$ & 68 & $19 \cdot 1$ & 442 & $10 \cdot 6$ & - & $29 \cdot 5$ & - & $19 \cdot 1$ & 554 & $19 \cdot 7$ \\
\hline Abdominal & 6 & $66 \cdot 7$ & $\mathbf{5}$ & $100 \cdot 0$ & 17 & $64 \cdot 7$ & - & - & 一 & - & $1094^{*}$ & $82 \cdot 0$ \\
\hline Genito-urinary & - & - & 2 & $50 \cdot 0$ & 39 & $20 \cdot 5$ & $\longrightarrow$ & - & - & $-\infty$ & 23 & $17 \cdot 4$ \\
\hline Miscellaneous & 9 & - & $\mathbf{3}$ & $\mathbf{3 3} \cdot \mathbf{3}$ & 33 & $12 \cdot 1$ & - & $\mathbf{3 3} \cdot 1$ & - & $9 \cdot 1$ & 23 & $8 \cdot 7$ \\
\hline All sites & & & & & & $32 \cdot 2$ & & & & & & $33 \cdot 7$ \\
\hline
\end{tabular}

Lupus and scrofulodermia excluded.

$\mathrm{B}=$ bovine.

* Figure taken from Report (1934).

Because of the gross excess of abdominal cases in Griffith's series, the percentage figures have been given equal weight for each site.

collected during the previous 20 years or so, and cannot be taken as corresponding in more than a general way to the incidence of bovine infections in that period. Moreover, there is no exact information on the origin of the material examined by Griffith, though it is fairly clear that it was not representative of the country as a whole. Little attention can be paid to the proportion of bovine infections in genito-urinary and miscellaneous lesions, as the figures are too few, but such as they are, they are fairly similar in the two series. The difference in the proportions for meningitis-28.1 and $24 \cdot 6 \%$ respectively-is less than its standard error. The difference for cervical glands, though infections are relatively as frequent now as they were 10 or 20 years ago; or it may be that Griffith drew his samples for examination more from the south and east of England, where bovine infections are less common, than from the north and west, where they are more common, and therefore obtained figures which were lower than they would have been if, as in our series, they had been based on samples taken from the country as a whole. The only conclusion that we can reach at present is that, so far as our figures are representative, approximately $26 \%$ (Table 1) of all non-pulmonary tuberculosis in 1943-5 was due to infection with the bovine type. 
A comparison between the two series 'at ages' shows that in Griffith's series the proportion of bovine infections was considerably higher in the 0-4-year than in the 5-14-year age group, whereas in our series the proportion in both age groups was about the same. Indeed, if Table 2 is consulted, it will be seen that the highest proportion of bovine infections in our series was in the 5-9-year age group. This presumably means that in Griffiths's time the ratio of bovine to human type infections was commonest in the infant and pre-school child, but that now it is commonest in the school child. The explanation of this interesting change in age distribution is probably twofold. In the first place, a great deal of attention has been paid during the last 25 years or so to infant feeding. Raw milk, which used to be commonly given to infants, is now seldom recommended; instead, artificially fed infants are brought up mainly on dried, boiled, or pasteurized milk, and so saved from the risk of infection with the bovine tubercle bacillus. A similar diet, supplemented by cereals and other foods, is often continued during the next 2 or 3 years of life. On the other hand, owing to the milk-in-schools scheme, many children now receive milk who previously would have had little or none once they had reached school age. It is true that a serious attempt has been made by most of the larger authorities to ensure a pasteurized or T.T. supply to the schools, but there is still an appreciable pro. portion of milk consumed raw under the scheme, particularly in small towns and country districts. The result has, therefore, been that a number of children have been infected at school with the bovine tubercle bacillus and that a number of pre-school children have been spared.

That non-pulmonary tuberculosis of bovine origin is not a disease confined entirely to children is shown very clearly in our series by the fact that approximately $30 \%$ of the cases occurred in persons over 15 years of age. The conclusion to be drawn from this is that immunity to bovine infection is not a natural concomitant of adult life, and that it is unwise to drink raw milk at any age. That adults may be susceptible not only to non-pulmonary infections with the bovine type of bacillus, but to pulmonary tuberculosis as well, has been demonstrated by Sigurdsson (1945) in Denmark, who was able to show that about $40 \%$ of adult cases of pulmonary tuberculosis in country districts in which the cattle were heavily infected were due to the bovine type of bacillus; infection had apparently occurred through direct infection by the cough-spray of the cattle.

(b) Estimated number of non-pulmonary tuberculosis deaths due to infection of bovine origin

Estimates of the annual number of deaths from tuberculosis of bovine origin have been made of recent years by the special committee appointed by the People's League of Health (Report, 1932), by the Committee on Cattle Diseases of the Economic Advisory Council (Report, 1934), and by Wilson (1942). These estimates have referred to deaths from tuberculosis of both pulmonary and non-pulmonary forms in England and Wales. If the non-pulmonary forms alone are considered, the figures are as follows: 1510 for the year 1929, 1874 for the year 1931, and 1603 for the year 1937. These estimates have suffered from two defects. In the first place the proportions of bovine infection for different sites of the disease have been based on samples of material examined over a period of many years and drawn from parts of the country that were not representative of England and Wales as a whole; and secondly, it has been assumed that the proportions of bovine infection in persons dying of the disease were the same as those in patients actually suffering from the disease.

In the present report an attempt is made to reach an estimate of the number of deaths from nonpulmonary tuberculosis of bovine origin in England alone in 1944. The first defect of the previous estimates has been largely avoided by basing the proportion of bovine infections on the results of material examined during 1943-5 and drawn from all parts of the country; but the second defect has been impossible to avoid, since practically the whole of the material sampled was derived from patients during life. It is a little difficult to assess the effect on the final result of the assumption that the proportion of bovine infections in persons dying of the disease is the same as that in living patients. If our figures were sufficiently numerous to provide reasonably accurate proportions for bovine infections at the different sites in the different age groups, and if we knew the total number of corresponding nonpulmonary deaths, the error introduced would probably be small. As it is, however, the number of samples examined from some sites of the disease-notably abdominal, genito-urinary, and miscellaneous-was too fow to permit of subdivision into ages, and the figures we have for the total number of non-pulmonary deaths in 1944, which were kindly supplied to us by the Registrar-General's Office, are themselves not subdivided according to age. We have, therefore, had to base our estimate on the proportion of bovine infections at all ages, treating the two sexes separately. The results are given in Table 14.

It will be seen that 651 males and 661 females are estimated to have died in England in 1944 from nonpulmonary tuberculosis of bovine origin-a total of 1312 persons. If the corresponding deaths for Wales are added, the total comes to 1361 . This estimate is lower than any of the three estimates already quoted for 1929,1931 , and 1937 respectively, but not too 
Table 14. Calculated number of deaths from non-pulmonary tuberculosis of bovine origin in England in 1944 (proportions based on Table 4; number of non-pulmonary tuberculosis deaths supplied by RegistrarGeneral's Office)

\begin{tabular}{|c|c|c|c|c|c|c|c|c|}
\hline Site of disease & \multicolumn{3}{|c|}{ Males } & \multicolumn{3}{|c|}{ Females } & \multicolumn{2}{|c|}{ Persons } \\
\hline Meningitis & 884 & $29 \cdot 5$ & 261 & 836 & $26 \cdot 4$ & 221 & 1720 & 482 \\
\hline Abdominal & 275 & $64 \cdot 7 *$ & 178 & 279 & $64 \cdot 7 *$ & 181 & 554 & 359 \\
\hline Bone and joint & 266 & $10 \cdot 1$ & 27 & 210 & $11 \cdot 4$ & 24 & 476 & 51 \\
\hline Total & 1,956 & $\mathbf{3 3} \cdot \mathbf{3}$ & 651 & 1,799 & $36 \cdot 7$ & 661 & $\mathbf{3 7 5 5}$ & 1312 \\
\hline
\end{tabular}

* As the proportions for abdominal tuberculosis given in Table 4 are based on so few cases, a combined rate for males and females has been substituted.

$\uparrow$ Includes adenitis other than mesenteric.

much attention can be paid to the difference, since the number of samples of material examined from some sites of the disease in all four inquiries was rather small. Nevertheless, there is a suggestion that at the present time the total number of nonpulmonary tuberculosis deaths due to the bovine type of bacillus is lower than it was 10 or 15 years ago.

\section{(c) Sex differences in proportion of bovine-type infections}

Another of our observations that calls for comment is the higher proportion of infections of bovine origin in females than in males. This is brought out in Table 4 (p. 342) and analysed more closely in Table 9 (p. 347). During the first 5 years of life the proportion in the two sexes is the same, but in the succeeding two age groups the difference between the male and female proportions increases till in the age group of 15 years and over the proportion of bovine infections in females is nearly double that in males. Is this due to the greater consumption of milk by females, or is it due to the same cause or causes that render young adult females more susceptible than males to pulmonary tuberculosis of human origin? Our data do not provide an answer to these questions. The second explanation would be more plausible if it concerned the greater susceptibility of females to non-pulmonary tuberculosis as a whole. Of this, however, there is no evidence. In fact, in 1944 more males died of non-pulmonary tuberculosis than females- 1956 as against 1799 . An explanation is therefore required to show why females are more likely than males to be infected with bacilli of the bovine type. The fact that the difference between males and females is evident in the 5-9-year age group, and, still more so in the 10-14-year age group, at a time when both sexes should be receiving about the same amount of milk, likewise throws doubt on the truth of the first explanation, but without exact data on the quantity and type of milk consumption by boys and girls of school age it is impossible to reach a definite conclusion.

\section{(d) Regional differences in proportion of bovine-type infections}

The different proportion of bovine to human infections in different parts of England is clearly apparent from Table 1 , and is rendered morecertain by Table 10 in which the figures have been standardized for age and sex. The lowest proportion of bovinetype infections is in the North-East and South-East regions and in the London area, the highest in the North-Midlands and the North-West. In the NorthMidlands the proportion is nearly three times that in the London area. We have tried to associate these differences with differences in the proportion of milk found to contain tubercle bacilli in the corresponding regions, but though there is a general association between them it is not of a high order. The reasons for this are probably manifold: thus, a proportion of the raw milk is bulked; a proportion is sent away and consumed in a different region from that in which it is produced; a comparatively high proportion of all milk is pasteurized or otherwise heat-treated; and infants and young children are fed largely on dried, boiled, pasteurized, or otherwise heat-treated milk. These and other factors tend to obscure the relationship between the regional differences in the proportion of infected milks and the proportion of non-pulmonary infections due to the bovine type in the different regions.

It may be asked why the London area, where nearly all milk is pasteurized, should have any tuberculosis of bovine origin at all. The answer is that Middlesex has been included in the London area, and that a certain amount of raw milk is still drunk in the county. Moreover, some of the patients 
Table 15. Comparison of proportion of raw milks from single herds found to contain tubercle bacilli in 1918-30 and 1936-44

\begin{tabular}{|c|c|c|c|c|c|c|}
\hline \multirow[b]{2}{*}{ Place } & \multicolumn{3}{|c|}{$1918-30$} & \multicolumn{3}{|c|}{$1936-44$} \\
\hline & $\begin{array}{l}\text { No. of samples } \\
\text { oxamined }\end{array}$ & No. T.B. + & T.B. $+(\%)$ & $\begin{array}{l}\text { No. of samples } \\
\text { examined }\end{array}$ & No. T.B. + & T.B. $+(\%)$ \\
\hline Newcastle & 3,057 & 161 & $5 \cdot 3$ & 3,366 & 173 & $5 \cdot 1$ \\
\hline Sheffield & 11,087 & 832 & $7 \cdot 5$ & 1,785 & 121 & $6 \cdot 8$ \\
\hline Hull & 449 & 30 & $6 \cdot 7$ & 1,583 & 76 & $4 \cdot 8$ \\
\hline Leeds & 878 & 36 & $4 \cdot 1$ & 1,835 & 57 & $3 \cdot 1$ \\
\hline Huddersfield & 237 & 15 & $6 \cdot 3$ & 1,668 & 73 & $4 \cdot 4$ \\
\hline Liverpool & 12,763 & 878 & $6 \cdot 9$ & 10,611 & 646 & $6 \cdot 1$ \\
\hline Blackburn & 1,804 & 37 & $2 \cdot 1$ & 2,755 & 102 & $3 \cdot 7$ \\
\hline Manchester & 4,802 & 620 & 12.9 & 10,005 & 923 & $9 \cdot 2$ \\
\hline Birmingham & 7,309 & 534 & $7 \cdot 3$ & 20,080 & 1,678 & $8 \cdot 4$ \\
\hline Brighton & 541 & 60 & $11 \cdot 1$ & 203 & 21 & $10 \cdot 3$ \\
\hline Reading & 282 & 31 & $11 \cdot 0$ & 339 & 12 & $3 \cdot 5$ \\
\hline Bristol & 450 & 30 & $6 \cdot 7$ & 883 & 55 & $6 \cdot 2$ \\
\hline Somerset & 1,327 & 31 & $2 \cdot 3$ & 3,960 & 161 & $4 \cdot 1$ \\
\hline Total & 44,986 & 3,295 & $7 \cdot 3$ & 59,073 & 4,098 & $6 \cdot 9$ \\
\hline
\end{tabular}

whose home was in London or Middlesex may have been infected while on holiday or during a short period of evacuation to the country. It will be observed, however, from Table 1 that the total number of cases in the London and Middlesex area was only eight, in spite of the fact that $12 \%$ of the population of England lived in this area, and that there were a number of collecting pathologists to supply material for typing.

It must be realized, of course, that Table 10 does not purport to estimate the risk of developing nonpulmonary tuberculosis of bovine origin in the different regions; it shows merely what the relative chance is, in any given region, of a non-pulmonary tuberculosis case being due to the bovine type. The low proportion of bovine infections in the NorthEast region is particularly striking, and has not, so far as we are aware, been noted by previous investigators. Possible reasons for this have already been discussed (p. 346).

\section{(e) Relative proportion of tuberculous raw milk now and formerly}

The last point calling for comment is suggested by Table 15 which seems to show that the proportion of farms sending out milk infected with tubercle bacilli is only slightly less than it was 15 or 20 years ago. The small decrease can be partly accounted for by the introduction and development of the Attested herds scheme. Thus, at the end of March 1945, Attested and T.T. herds together constituted 5.4\% of the total dairy herds in England. This figure is close to that of $5 \cdot 5 \%$, which represents the reduction in the proportion of milks containing tubercle bacilli, and suggests that little alteration has occurred during

the past 20 years or so in the proportion of nontuberculin-tested herds infected with tuberculosis.

It is doubtful whether the introduction of the Accredited herds scheme has had any appreciable effect, since the proportion of Accredited herds sending out tuberculous milk does not appear to differ materially from that of ordinary herds.

\section{Summary and conclusions}

1. The present inquiry was designed to provide information on the relative frequency of infection in non-pulmonary tuberculosis with the human and bovine type of tubercle bacillus throughout the whole of England. A total of 149 pathologists at 120 collecting centres and 32 bacteriologists at 27 typing centres took part in the scheme. Two questionnaires relating to each patient were used, one to be filled in by the laboratory workers and one by the Tuber. culosis Officer or other responsible official.

2. Altogether tubercle bacilli were isolated and typed from 994 patients. Of these strains, 261 or $26.3 \%$ belonged to the bovine and 733 or $73.7 \%$ to the human type (Table 1).

3. The proportion of bovine-type infections at all ages was as follows: meningitis $28.0 \%$, cervical adenitis $57.5 \%$, bone and joint tuberculosis $10.6 \%$, abdominal tuberculosis $64.7 \%$, genito-urinary tuberculosis $22.5 \%$, and tuberculosis of other sites $11.8 \%$ (Table 1).

4. Analysis of the frequency at different ages showed that, in contradistinction to previous figures, which have always been highest in the first 5 years of life, the maximum proportion of bovine-type infections in the present series was in the 5-9-year age group (Table 2). This is attributed partly to the 


\section{Non-pulmonary tuberculosis in England and in Wales}

gradual replacement of raw by dried, boiled, or pasteurized milk for infant feeding, which has served to protect the child in the early years of life, and to the introduction of the milk-in-schools scheme, which has resulted in the exposure of a considerable number of school children to the risks of drinking raw milk who otherwise might have escaped infection. The conclusion is that, in view of the beneficial nutritive effect of milk for children, every effort should be made in future to supply pasteurized or otherwise heat-treated milk to schools.

5. No fewer than $30 \%$ of infections of bovine origin occurred in persons of 15 years of age or over, showing that the risks attendant on drinking raw milk are not confined to children.

6. Approximately $40 \%$ of all cases of nonpulmonary tuberculosis in children under 15 years of age, $15 \%$ of cases in persons aged 15 years and over, and $25 \%$ of cases at all ages were due to infection with the bovine type.

7. Analysis of the sex incidence of bovine-type infections showed no difference during the first 5 years of life. During subsequent years, however, the difference between the male and female proportions increased more or less progressively till in the age group 15 years and over the proportion of bovine infections in females was almost double that in males (Tables 4 and 9). How much of this difference can be ascribed to the greater amount of milk drunk by fermales, and how much to other factors, it is impossible to say. It must be made clear that the greater susceptibility of females is a differential susceptibility to infection with the bovine type, not to non-pulmonary tuberculosis as a whole.

8. Of the patients for whom an adequate history was obtainable, $9.4 \%$ infected with the bovine and $\mathbf{2 5 . 8} \%$ infected with the human type gave a history of contact with an open case of pulmonary tuberculosis (Table 5).

9. In cases due to infection with the human type a history of contact was obtained in over half the patients under 5 years of age, but in only about a quarter at later ages (Table 6). The fact that no history of contact was forthcoming in $44 \%$ of patients in the 0-4-year age group suggests either that tuberculous patients in the child's home had been overlooked, or that tuberculous infection outside the home must be very common, even in the limited environment of the young child.

10. In cases due to infection with the bovine type, a history of contact was commonest in patients over 15 years of age, who had naturally had longer to experience such a risk than younger children. It may be assumed that all these patients were infected from raw milk, and that their exposure to human infection was fortuitous and played no part in the genesis of their disease. Owing to the frequency of tuberculosis in the general population, it is clear that many

J. Hygiene 47 persons who develop tuberculosis must be exposed to more than one source of infection. If the figure of $9.4 \%$ represents the frequency with which a contact history would be obtained for any group of persons having a similar age, sex, and social distribution to that in the present series, it follows that in only two out of three cases of tuberculosis due to the human type of bacillus will a history of contact point to the true source of infection.

11. Of patients for whom information was available, $\mathbf{2 3 . 6} \%$ infected with the human and $\mathbf{2 6 . 4} \%$ with the bovine type had changed their residence since the outbreak of war, either as the result of evacuation or for other reasons. Since the corresponding proportion among persons who did not contract non-pulmonary tuberculosis is unknown, it is impossible to say how far change of residence predisposed to the development of disease. Study of the individual case sheets, however, revealed a number of instances in which patients infected with the human type were brought as a result of their move into contact with open cases of tuberculosis, and in which patients infected with the bovine type were transferred as a result of their move from a pasteurized to a raw milk supply.

12. Of patients for whom information was available, $86.7 \%$ infected with the bovine, and $53.0 \%$ infected with the human type, gave a history of drinking raw milk (Table 8). The difference between these proportions is highly significant, and indicates that persons consuming raw milk are more likely to develop infection due to the bovine type of bacillus than those drinking heat-treated milk. Study of the individual case sheets revealed a number of instances of bovine infection among the families of farmers and in persons visiting or living on farms, among infants who had been brought up on the breast or on dried milk and transferred to raw milk, and among children who had pasteurized milk at home but raw milk at school.

13. Standardization of the data for age and sex according to the site of disease showed a striking difference between the ratio of observed to expected cases of non-pulmonary tuberculosis due to the bovine type in different parts of the country (Tables 9 and 10). The highest proportion of bovine-type infections occurred in the North-Midland and North. West regions, the lowest in the North-East and South-East regions and in the London area, the proportions in the first two regions being about three times those in the last three.

14. For reasons that are put forward in the text (p. 345) no high degree of correlation could be established between the proportion of Attested and T.T. herds, or between the proportion of raw milk containing tubercle bacilli, and the proportion of bovine-type infections in the different regions. It may be noted that the proportion of dairy herds 
sending out milk containing tubercle bacilli is almost as high now as it was 20 years ago- $6.9 \%$ as against $7 \cdot 3 \%$ (Table 15). The slight decrease can be almost entirely accounted for by the establishment of Attested and T.T. herds, which on 31 March 1945, constituted $5.4 \%$ of all dairy herds.

15. Apart from the 994 cases of non-pulmonary tuberculosis from which tubercle bacilli were isolated, 172 cases were studied from which no tubercle bacilli could be isolated. Of these, 139 were cases diagnosed as cervical glandular tuberculosis (Table 12). The incidence in these cases was practically the same in males and females and, apart from the lower proportion in the first 5 years of life, no special age predisposition was noticeable. No less than $77 \%$ of the cases occurred in the North-East, NorthMidland, and South-West regions, but whether this was due to the greater interest of the pathologists in these areas in this type of case or to other reasons cannot be said. How many of these cases were due to tuberculous infection and how many to other causes was not ascertained.

By applying the proportions recorded in Table 4 to data for 1944, it is calculated that approximately 1300 persons died in that year in England from nonpulmonary tuberculosis of bovine origin (Table 14). Comparison of this figure with estimates made by previous workers, and with the proportions of bovine-type infections given by Griffith in 1938 (Table 13), shows an apparent, though slight, reduction in the amount of disease caused by the bovine type of bacillus during the past 15 years or so.
Whether this represents the real reduction, or whether it underestimates it owing to the fact that previous estimates were based on samples of material drawn mainly from areas of the country in which the bovine type of infection is less common and were therefore too low, cannot be determined, but the second proposition would seem to be the more probable. Whichever is correct, the solemn truth remains that, omitting pulmonary tuberculosis, about 1300 persons are dying in England each year from a preventable disease. There is every reason to believe that if all milk for human consumption throughout the country could be adequately heattreated, tuberculosis of bovine origin would be practically abolished.

Acknowledgement must be expressed to the numerous collecting pathologists who supplied material for examination and clinical information about the patients, and to the typing bacteriologists who examined and reported on it; to Dr J. A. Young for acting as reference expert for the typing of doubtful strains of tubercle bacilli; to the Tuberculosis Officers and other responsible officials who filled up Form B; to the Medical Officers of Health who provided figures on the frequency of infection with tubercle bacilli of milk sampled in their area; to the Registrar-General's office for the regional distribution of deaths from different forms of non-pulmonary tuberculosis in 1944; and to Prof. A. Bradford Hill and Dr E. A. Cheeseman for their detailed and helpful criticism of the report.

\section{NON-PULMONARY TUBERCULOSIS IN WALES}

The investigation in Wales was carried out in essentially the same way and over the same period of time as in England, the main difference being that all strains were typed by a single bacteriologist in Cardiff (Prof. Tytler).

\section{Distribution of specimens according to area of origin}

Table 16 shows the distribution of strains according to the part of Wales or Monmouthshire in which the patients were living.

Altogether 112 strains were studied; of these, 93 belonged to the human and 19 to the bovine type. Approximately $60 \%$ of the strains came from patients residing in the fairly densely populated areas of South Wales-Cardiff, Swansea, Glamorgan, Newport, and Monmouth; $17.6 \%$ of these belonged to the bovine type, as opposed to $15.9 \%$ of those from the more rural districts of the rest of Wales. The numbers are too few to justify standardization for age and sex, and the only conclusion to be reached
Table 16. Distribution of specimens according to county or county borough in which the patients were resident

Bovine

Cardiff

Swansea

County of Glamorgan

Human Bovine Total (\%)

(excluding above)
Newport and Monmouth $\quad \begin{array}{llll}1 & 1 & 2 & (50)\end{array}$

$\begin{array}{llrrc}\text { Carmarthen } & 8 & 2 & 10 & 20 \\ \text { Pembroke } & 2 & 1 & 3 & 33 \cdot 3\end{array}$

Brecon

Cardigan

Caernarvon

Anglesey

Flint

Denbigh

Merioneth, Montgomery and Radnor

Total

$\begin{array}{ccrc}11 & 2 & 13 & 15 \cdot 4 \\ 14 & 3 & 17 & 17 \cdot 6 \\ 30 & 6 & 36 & 16 \cdot 7 \\ & & & \\ 1 & 1 & 2 & (50) \\ 8 & 2 & 10 & 20 \\ 2 & 1 & 3 & 33 \cdot 3 \\ 0 & 1 & 1 & (100) \\ 9 & 1 & 10 & 10 \\ 11^{*} & 0 & 11 & (0) \\ 5 & 2 & 7 & 28 \cdot 6 \\ 1 & 0 & 1 & (0) \\ 1^{*} & 0 & 1 & (0) \\ 0 & 0 & 0 & -\end{array}$

$\begin{array}{llll}93 & 19 & 112 & 17.0\end{array}$

* Includes two cases, members of H.M. Forces in hospital in the area. Note: Percentages based on very small numbers of figures are put in brackets. 
Table 17. Distribution of human and bovine types according to age of patient and site of disease

\begin{tabular}{|c|c|c|c|c|c|c|c|c|c|c|c|c|c|c|c|}
\hline \multirow[b]{3}{*}{ Site of disease } & \multicolumn{14}{|c|}{ Age of patient } & \multirow[b]{3}{*}{$\begin{array}{c}\text { Bovine } \\
(\%)\end{array}$} \\
\hline & \multicolumn{2}{|c|}{0} & \multicolumn{2}{|c|}{$5-$} & \multicolumn{2}{|c|}{10} & \multicolumn{2}{|c|}{$15-$} & \multicolumn{2}{|c|}{$20-$} & \multicolumn{2}{|c|}{$25+$} & \multicolumn{2}{|c|}{ All ages } & \\
\hline & $\mathbf{H}$ & $\mathbf{B}$ & $\mathbf{H}$ & $\mathbf{B}$ & $\mathbf{H}$ & $\mathbf{B}$ & $\mathrm{H}$ & B & $\mathbf{H}$ & $\mathbf{B}$ & $\mathbf{H}$ & B & $\mathbf{H}$ & B & \\
\hline Meningitis & 19 & 4 & 10 & 1 & 10 & 1 & 6 & 一 & 7 & - & 10 & 1 & 62 & 7 & $10 \cdot 1$ \\
\hline Cervical glands & 2 & 3 & 1 & - & 2 & $\mathbf{3}$ & 1 & 1 & 1 & - & $\mathbf{3}$ & 1 & 10 & 8 & $44 \cdot 4$ \\
\hline Bone and joint & 1 & 1 & - & $\ldots$ & - & - & 1 & 1 & 3 & 1 & 12 & 1 & 17 & 4 & $19 \cdot 0$ \\
\hline Abdominal & - & - & - & - & - & - & 1 & - & - & - & - & - & I & - & $(0)$ \\
\hline Genito-urinary & - & - & - & - & - & - & 一 & 一 & 一 & - & 3 & - & 3 & - & $(0)$ \\
\hline All sites & 22 & 8 & 11 & 1 & 12 & 4 & 9 & 2 & 11 & 1 & 28 & 3 & 93 & 19 & $17 \cdot 0$ \\
\hline Bovine (\%) & \multicolumn{2}{|c|}{$26 \cdot 7$} & \multicolumn{2}{|c|}{$8 \cdot 3$} & \multicolumn{2}{|c|}{$25 \cdot 0$} & \multicolumn{2}{|c|}{$18 \cdot 2$} & \multicolumn{2}{|c|}{$8 \cdot 3$} & \multicolumn{2}{|c|}{$9 \cdot 7$} & \multicolumn{2}{|c|}{$17 \cdot 0$} & \\
\hline
\end{tabular}

Table 18. Distribution of human and bovine types according to sex of patient and site of disease

\begin{tabular}{|c|c|c|c|c|c|c|c|c|c|}
\hline \multirow[b]{2}{*}{ Site of disease } & \multicolumn{3}{|c|}{ Males } & \multicolumn{3}{|c|}{ Females } & \multicolumn{3}{|c|}{ Persons } \\
\hline & $\mathrm{H}$ & $\mathrm{B}$ & $\% \mathrm{~B}$ & $\mathbf{H}$ & $\mathbf{B}$ & $\% \mathrm{~B}$ & $\mathbf{H}$ & B & $\% \mathrm{~B}$ \\
\hline Meningitis & 29 & 1 & $\mathbf{3} \cdot \mathbf{3}$ & 33 & 6 & $15 \cdot 4$ & 62 & 7 & ] $0 \cdot 1$ \\
\hline Cervical glands & 6 & 6 & $50 \cdot 0$ & 4 & 2 & $33 \cdot 3$ & 10 & 8 & $44 \cdot 4$ \\
\hline Bone and joint & 10 & 3 & $23 \cdot 1$ & 7 & 1 & $12 \cdot 5$ & 17 & 4 & $19 \cdot 0$ \\
\hline Abdominal & 1 & - & $(0 \cdot 0)$ & - & - & - & 1 & - & $(0.0)$ \\
\hline Genito-urinary & - & - & - & 3 & 一 & $(0 \cdot 0)$ & $\mathbf{3}$ & - & $(0.0)$ \\
\hline All sites & 46 & 10 & $17 \cdot 9$ & 47 & 9 & $16 \cdot 1$ & 93 & 19 & $17 \cdot 0$ \\
\hline
\end{tabular}

Table 19. Contact history according to human or bovine type

$\begin{array}{cccccc}\text { Type } & \text { Contact }+ & \text { Contact } & \text { No information } & \text { Total } & \text { Contact }+(\%)^{*} \\ \text { H } & 16 & 71 & 6 & 93 & 18 \cdot 4 \\ \text { B } & 1 & 14 & 4 & 19 & 6 \cdot 7 \\ \text { Both } & 17 & 85 & 10 & 112 & 16 \cdot 7\end{array}$

* Based on cases in which information was available.

is that, with the possible exception of Caernarvonshire in which no case of bovine infection was found, there is no obvious difference in the geographical distribution of the two types of tubercle bacilli.

\section{Distribution of human and bovine types according to age of patient and site of disease}

Table 17 summarizes the distribution of human and bovine types according to the age of the patient and the site of the disease.

So far as the smallness of the figures allows, it would appear as if the highest proportion of bovine infections is met with in the first 5 years of life. It is difficult to say, however, whether the fall in the next two age groups is genuine or only apparent through the errors of random sampling. It may be noted that 6 out of the 19 bovine strains were isolated from patients aged 15 years or more. Examination of the individual records revealed one case of cervical glandular tuberculosis in a patient over 40, one of meningitis in a patient over 45 , and one of bone and joint tuberculosis in a patient over 60 years of age.
It will be seen that 69 of the 112 strains came from cases of meningitis. This high proportion may have been due to the circumstance that most of the specimens were sent in to public health laboratories, which derive their work more from isolation hospitals than from general hospitals or sanatoria.

\section{Distribution of human and bovine types according to sex of patient and site of disease}

Table 18 sets out the distribution of human and bovine types according to the sex of the patient and the site of disease.

It will be seen that equal numbers of specimens were examined from males and females, and that the proportion of bovine infections was about the same in the two sexes.

\section{Contact history according to human and bovine type}

Table 19 records the frequency with which a history of contact with an open case of pulmonary 
Table 20. History of human contact according to age of patient and site of disease (human cases only)

\begin{tabular}{|c|c|c|c|c|c|c|c|c|c|c|}
\hline \multirow[b]{3}{*}{ Site of disease } & \multicolumn{8}{|c|}{ Age of patient } & & \\
\hline & \multicolumn{2}{|c|}{$0-$} & \multicolumn{2}{|c|}{$5-$} & \multicolumn{2}{|c|}{$10-$} & \multicolumn{2}{|c|}{$15+$} & \multicolumn{2}{|c|}{ Total } \\
\hline & Contact & $\begin{array}{c}\text { No } \\
\text { contret }\end{array}$ & Contact & $\begin{array}{c}\text { No } \\
\text { contact }\end{array}$ & Contact & $\begin{array}{c}\text { No } \\
\text { contact }\end{array}$ & Contact & $\begin{array}{c}\text { No } \\
\text { contact }\end{array}$ & Contact & $\begin{array}{c}\text { No } \\
\text { contact }\end{array}$ \\
\hline Meningitis & 9 & 8 & 2 & 7 & 一 & 9 & 2 & 20 & 13 & 44 \\
\hline Cervical glands & - & 2 & 一 & 1 & - & 2 & - & 5 & - & 10 \\
\hline Bone and joint & $\ldots$ & 1 & - & - & - & - & 3 & 12 & 3 & 13 \\
\hline Abdominal & - & - & - & - & - & - & 一 & 1 & - & I \\
\hline Genito-urinary & - & - & - & - & - & $\longrightarrow$ & - & 3 & 一 & 3 \\
\hline Total & 9 & 11 & 2 & 8 & - & 11 & 5 & 41 & 16 & 71 \\
\hline $\begin{array}{l}\text { Percentage with } \\
\text { history of cont }\end{array}$ & \multicolumn{2}{|c|}{45} & \multicolumn{2}{|c|}{20} & \multicolumn{2}{|c|}{ (0) } & \multicolumn{2}{|c|}{$10 \cdot 9$} & \multicolumn{2}{|c|}{$18 \cdot 4$} \\
\hline
\end{tabular}

Note. From four cases of meningitis in the 0-4-year age group, from one case of bone and joint infection in the $15+$-year age group, and from one case of genito-urinary infection in the $15+$-year age group, no information was obtainable.

Table 21. History of raw milk consumption

$\begin{array}{lccccc}\text { Raw } & \text { No raw } & \begin{array}{c}\text { No } \\ \text { information }\end{array} & \begin{array}{c}\text { Percentage with history } \\ \text { of habitual raw milk } \\ \text { consumption* }\end{array} \\ \text { Hovine } & 41 & 33 & 19 & 93 & 55 \cdot 4 \\ \text { Total } & 12 & 3 & 4 & 19 & 80 \cdot 0 \\ & 53 & 36 & 23 & 112 & 59 \cdot 6\end{array}$

* Based on cases in which information was obtainable.

tuberculosis was obtained. The figures show that a history of contact was about three times as common in patients infected with the human as with the bovine type. Table 20 analyses the cases infected with the human type only.

It will be seen that, of the cases about which information was obtainable, the highest proportion of those with a history of contact occurred in the 0-4-year age group, namely $45 \%$. Such a history was also obtainable more often in cases of meningitis than in cases of other types, namely $22.8 \%$. Even this figure is very low, showing that the source of infection is not usually detected.

The bovine cases are too few to justify a separate table. No information was obtainable about four of the cases, and only one of the remaining fifteen gave a history of contact. This case was a patient of 43 years of age suffering from cervical adenitis, whose mother had pulmonary tuberculosis.

Relationship between change of residence and infection with human or bovine type of tubercle bacillus

Of 107 patients for whom a history was obtainable, 42 or $39.3 \%$ had changed their residence within the previous 6 years. There appeared to be no difference in this respect between patients infected with the human and those infected with the bovine type. Only three of the patients were officially labelled evacuees.

\section{Consumption of raw milk according to human and bovine types}

In Table 21 the cases are analysed according to a history of raw milk consumption.

The figures are unsatisfactory, as no information on the nature of the milk supply was obtainable from 23 of the 112 patients. Of the rest, it will be seen that a higher proportion $(80 \%$ ) of those infected with the bovine type gave a history of drinking raw milk than of those infected with the human type $(55.4 \%)$. Owing to the smallness of the figures, the difference of $24 \cdot 6 \pm 13.9 \%$ is not statistically significant. It should be noted, however, that the question asked was whether raw milk had been consumed habitually. The information contained in the table, that $20 \%$ of the bovine cases had not habitually drunk raw milk, does not mean that they had never drunk raw milk. In two out of three fatal bovine cases, for example, with no history of drinking raw milk, primary abdominal tuberculosis was found on post-mortem examination, pointing strongly to an alimentary milk-borne infection.

\section{Cases not proved bacteriologically to be tuberculous}

Table 22 sets out the distribution according to age and site of disease of the patients from whom no tubercle bacilli were isolated. 
Table 22. No tubercle bacilli isolated (distribution according to age of patient and site of disease)

\begin{tabular}{|c|c|c|c|c|c|c|}
\hline \multirow[b]{2}{*}{ Site of disease } & \multicolumn{4}{|c|}{ Age of patient } & \multicolumn{2}{|c|}{ All ages } \\
\hline & 0 & $5-$ & 10 & $15+$ & No. & Percentage \\
\hline Meningitis & I & 1 & - & $\mathbf{3}$ & 5 & 15 \\
\hline Cervical glands & 3 & 2 & I & a & 15 & 45 \\
\hline Bone and joint & - & - & - & 5 & 5 & 15 \\
\hline Abdominal & - & I & - & 4 & 5 & 15 \\
\hline Genito-urinary & - & - & - & 1 & 1 & 3 \\
\hline Miscellaneous & - & 1 & - & 1 & 2 & 6 \\
\hline All sites (no.) & 4 & 5 & 1 & 23 & $\mathbf{3 3}$ & 99 \\
\hline All sites percentage & $12 \cdot 1$ & $15 \cdot 2$ & $3 \cdot 0$ & $69 \cdot 7$ & $100 \cdot 0$ & \\
\hline
\end{tabular}

Table 23. Calculated number of deaths from non-pulmonary tuberculosis of bovine origin in Wales in 1944 (proportions based on Table 18; number of non-pulmonary tuberculosis deaths supplied by the RegistrarGeneral's Office)

\begin{tabular}{|c|c|c|c|c|c|c|c|c|}
\hline \multirow[b]{2}{*}{ Site of disease } & \multicolumn{3}{|c|}{ Males } & \multicolumn{3}{|c|}{ Females } & \multicolumn{2}{|c|}{ Persons } \\
\hline & $\begin{array}{l}\text { Total } \\
\text { deaths }\end{array}$ & $\begin{array}{c}\text { Bovine } \\
(\%)\end{array}$ & $\begin{array}{l}\text { Estimated } \\
\text { no. bovine }\end{array}$ & $\begin{array}{c}\text { Total } \\
\text { deaths }\end{array}$ & $\begin{array}{c}\text { Bovine } \\
(\%)\end{array}$ & $\begin{array}{l}\text { Estimated } \\
\text { no. bovine }\end{array}$ & $\begin{array}{c}\text { Total } \\
\text { deaths }\end{array}$ & $\begin{array}{l}\text { Estimated } \\
\text { no. bovine }\end{array}$ \\
\hline Meningitis & 58 & $3 \cdot 3$ & 2 & 63 & $15 \cdot 4$ & 10 & 121 & 12 \\
\hline Abdominal & 22 & $0 \cdot 0$ & 0 & 29 & $0 \cdot 0$ & 0 & 51 & 0 \\
\hline Bone and joint & 30 & $23 \cdot 1$ & 7 & 17 & $12 \cdot 5$ & 2 & 47 & 9 \\
\hline Genito-urinary & 13 & - & - & 6 & $0 \cdot 0$ & 0 & 19 & 0 \\
\hline Miscellanөous* & 31 & $50 \cdot 0$ & 16 & 35 & $33 \cdot 3$ & 12 & 66 & 28 \\
\hline Total & 154 & $16 \cdot 2$ & 25 & 150 & $14 \cdot 7$ & 24 & 304 & 49 \\
\hline
\end{tabular}

* Includes adenitis other than mesenteric.

It will be observed that about $70 \%$ of the patients were 15 years of age or over, and that nearly half of the patients were suffering from cervical adenitis. These figures differ widely from those in Table 17, in which only $36 \%$ of the patients were in the $15+$-year age group and only $16 \%$ were suffering from cervical adenitis.

\section{Discussion}

The findings in the Welsh investigation may be briefly compared with those in the English investigation, which have already been described in the first part of this paper.

(a) In Wales the proportion of infections with the bovine type of tubercle bacillus was only $17.0 \%$ compared with $26.3 \%$ in England. One reason for this difference is the much higher proportion of meningitis cases examined in Wales than in England, the figures being $62 \%$ and $26 \%$ respectively. Since only $10.1 \%$ of the Welsh meningitis cases were infected with the bovine type as against $28.0 \%$ in England, the effect of this difference in distribution is considerable. Had the cervical gland and the bone and joint cases in Wales formed as high a proportion of the total cases as in England, the bovine percentage in Wales would have been about $20 \%$.
Even this figure is considerably below the English figure of $26.3 \%$.

One factor that may well have played a part in causing this difference is the higher proportion of Attested (i.e. tubercle-free) herds in Wales. In 1946, for example, $21.3 \%$ of all cattle in Wales were Attested, as opposed to $\mathbf{5 . 4} \%$ in England. Taking this in conjunction with the fact that, during the time of the inquiry, the proportion of pasteurized or heat-treated milk sold was $80 \%$ in Cardiff, $56 \%$ in Swansea, and about $68 \%$ in the other urban districts of Glamorganshire, it follows that the milk supply in Wales was almost certainly less often infected with tubercle bacilli than in England.

Another possible factor responsible for the lower proportion of bovine infections in Wales is that the risk of infection with the human type from open cases of pulmonary tuberculosis may have been greater. There is no exact information available to judge the truth of this explanation. The only permissible conclusion is that, whatever the reasons, the chances of a non-pulmonary tuberculosis case being due to the bovine type of bacillus are less in Wales than in England.

(b) In the English investigation a higher proportion of bovine infections was found in females than in males. In the Welsh investigation the pro- 
portion was almost identical for the two sexes. Unfortunately, there were too few cases to justify an analysis of the sexes according to age, and it was therefore not possible to see whether, as in England, the difference in the proportion of bovine infections in males and females increased with age up to 15 years.

(c) In England the highest proportion of bovine infections was found in the 5-9-year age group: in Wales the highest proportion was in the 0-4-year age group. The numbers, however, in the Welsh inquiry were so few, and the proportions in the 5-9-, 10-14- and 15-19- year age groups were so irregular as to render it dangerous to conclude without further evidence that the age distribution of bovine infections in Wales was substantially different from that in England.

(d) In both inquiries a considerably higher proportion of patients infected with the bovine type gave a history of drinking raw milk than of those infected with the human type. This, of course, is what would be expected from our previous knowledge of the part played by raw milk in the transmission of the bovine tubercle bacillus to man.

(e) It is interesting that in both the Finglish and the Welsh investigations a considerable number of specimens examined failed to yield tubercle bacilli on culture or guinea-pig inoculation. The two investigations further agreed in showing that this type of specimen came most often from cases of cervical adenitis, and from patients aged 15 years and over. It seems clear that there is a problem here which might well repay study.

(f) In England, approximately $40 \%$ of all cases of non-pulmonary tuberculosis in children under 15 years of age, and $15 \%$ of cases in persons aged 15 years and over were found to be of bovine origin. The corresponding proportions in Wales were 22 and $11 \%$. On the basis of these figures it may be calculated that in 1944 approximately $24 \%$ of cases of non-pulmonary tuberculosis at all ages in England and Wales were due to infection with the bovine type of bacillus.

(g) An attempt has been made in Table 23 to estimate the number of deaths in Wales from nonpulmonary tuberculosis of bovine origin during the year 1944.

The number of cases in some of the groups are very few, and the bovine percentages taken from Table 18 cannot be regarded as more than crude approximations. Probably the greatest error comes from assuming that none of the abdominal cases was due to infection with the bovine type. Table 18 shows that, in fact, only one case of abdominal tuberculosis was examined, and this happened to be in an adult and caused by the human type. All our previous experience has indicated that in children $80-90 \%$ of primary abdominal tuberculosis is of bovine origin, and the figure of 0 in Table 23 for this number of deaths from abdominal tuberculosis caused by the bovine bacillus is almost certainly a gross understatement. It will be seen that in Wales forty-nine deaths are estimated to have been caused by the bovine type of bacillus. This figure may be compared with that of 1312 for England.

\section{Summary and conclusions}

1. Tubercle bacilli were isolated and typed from 112 patients in Wales. Of these strains, 19 or $17.0 \%$ belonged to the bovine and 93 or $83 \%$ to the human type ('Table 16).

2. The proportion of bovine-type infections at all ages was as follows: meningitis $10 \cdot 1 \%$, cervical adenitis $44.4 \%$, and bone and joint tuberculosis $19.0 \%$ (Table 17).

3. The proportion of bovine infections was $22.4 \%$ under 15 years of age and $11.1 \%$ at 15 years and over.

4. No appreciable difference was found in the proportion of bovine infections between males and females (Table 18).

5. A history of exposure to contact with an open case of pulmonary tuberculosis was obtained in $18.4 \%$ of cases of human-type infection about which information was available, and in $6.7 \%$ of cases of bovine-type infection (Tables 19 and 20 ).

6. Of patients infected with the bovine type about whom information was available, $80 \%$ gave a history of habitual raw milk consumption, as against $55.4 \%$ of patients infected with the human type (Table 21).

7. From thirty-three cases examined no tubercle bacilli were isolated. The commonest lesion from which negative findings were recorded was cervical adenitis, and the commonest age group 15 years and over (Table 22).

8. Comparison with the English tigures shows that the proportion of bovine-type infections in nonpulmonary tuberculosis is lower in Wales than in England. Two or three factors may be responsible for this difference, but undoubtedly one important factor is the much higher proportion of cattle in Attested herds in Wales than in England-21.3\% as against $5.4 \%$. Considered in conjunction with the fairly high proportion of milk pasteurized or heattreated in the larger towns of South Wales, this may be taken to indicate that the milk supply to the public is probably less often infected with tubercle bacilli in Wales than in England.

9. Applying the proportions of bovine-type infections recorded in Table 18 to the deaths from different forms of non-pulmonary tuberculosis listed by the Registrar-General, it may be calculated that in Wales about fifty persons died in 1944 from tuberculosis of bovine origin (Table 23). 
10. Taking the figures for the two countries together, it may be said that about $24 \%$ of all cases of non-pulmonary tuberculosis were due to infection with the bovine type of tubercle bacillus, and that between 1300 and 1400 persons died in 1944 from tuberculosis of bovine origin. It is submitted that probably none of these deaths would have occurred if the milk supply had been adequately pasteurized.

\section{REFERENCES}

BATEX, H. (1948). Tubercle, 29, 174.

Clark, K. C., Hart, P. D'A., Kerley, P. \& Thompson, B. C. (1945). Spec. Rep. Ser. Med. Res. Coun, Lond., no. 251.

GRIFFTth, A. S. (1938). Proc. R. Soc. Med. 31, 1208.

REPORT (1932). A Survey of Tuberculosis of Bovine Origin in Great Britain. People's League of Health, London.

REPORT (1934). Economic Advisory Council, Committee on Cattle Diseases. London: H.M. Stationery Office.
RePort (1942). Spec. Rep. Ser. Med. Res. Coun., Lond., no. 246.

SraURDsson, J. (1945). Studies on the Risk of Infection with Bovine Tuberculosis to the Rural Population, with Special Reference to Pulmonary Tuberculosis. London: Oxford University Press.

Topley, W. W. C. \& Wrlson, G. S. (1946). The Principles of Bacteriology and Immunity, p. 1290. Third ed. revised by G. S. Wilson and A. A. Miles. London: Arnold and Co.

WILson, G. S. (1942). The Pasteurization of Milk. London: Arnold and Co.

(MS. received for publication 25. vIIr. 49.-Ed.) 